\title{
Rocking the boat
}

\section{The participation rhetoric exposed: why should people living in poverty have a voice and space at the United Nations?}

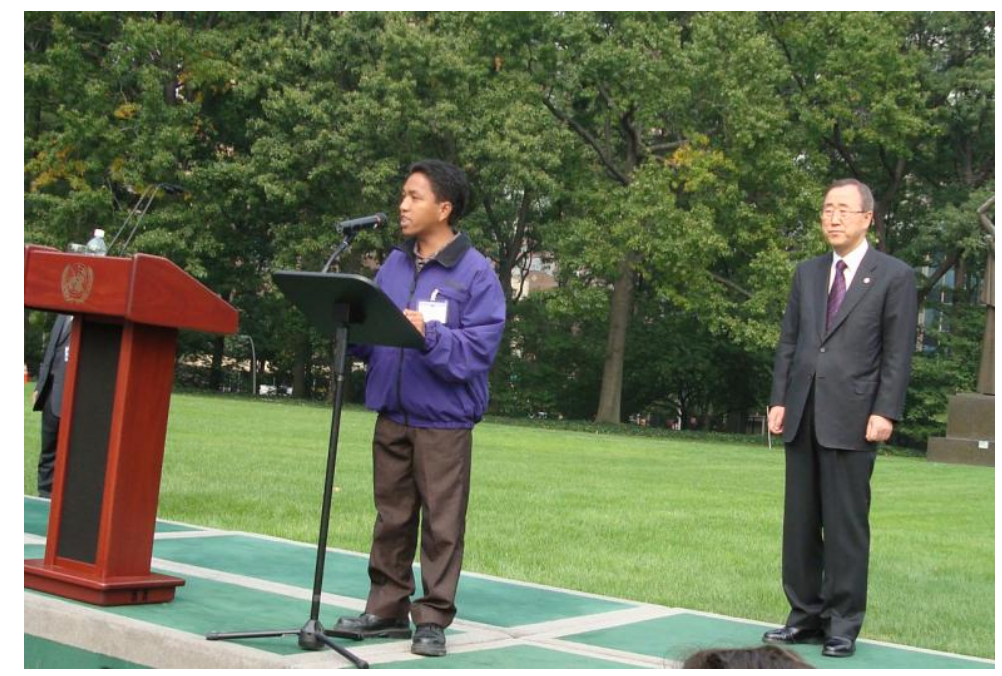

Research Thesis INTP 595

Submitted in partial fulfilment of the requirements of a

Masters of International Relations,

School of Political Science and International Relations,

Victoria University of Wellington

April 2010

by

Vicki Soanes 
This thesis is for the many women, men and children of the Fourth World with whom I was so fortunate to share some of my life, and who taught me that the worst violation of human rights is to be rendered invisible. I was privileged to have them as my teachers. Although I cannot name them all, I am particularly grateful to Aling Tita Villarosa, Doña Lorena Tepeu, Mr Adonis Salas and Ms Emma Speaks for lending me their inspiration for this thesis.

Thank you to my friends from the NGO community in New York who are so welcoming to all who want to make a positive contribution at the UN. It is truly a supportive community that shares knowledge in order to make positive change. This thesis is intended as a respectful contribution to that dynamic.

Many thanks to Dr Kate Schick and Dr Robbie Shilliam for their support and guidance. Love and thanks to Donnchadh, Ruadh, Stephen and my Soanes whanau.

For Grandad.

And to all of the activists, volunteers and supporters of ATD Fourth World who work so hard to defend the rights of the most vulnerable. I hope I have done justice to this important issue. 


\section{Acronyms}

CONGO

CSocD

CSW

DCF

DESA

ECOSOC

FAO

FFD

FGO

Fourth World

GCAP

GDP

Global North

Global South

INGO

MBOP

MDGs

NIEO

NGO

ODA

PRSPS

UN

UNCTAD

UNDP

UNICEF

UN-NGLS

UNSG

WEDO

WFP
Conference of Non-Governmental Organisations in Consultative Relationship with the United Nations

Commission for Social Development

Commission on the Status of Women

Development Co-operation Forum

United Nations Department of Economic and Social Affairs

Economic and Social Council

Food and Agriculture Organisation

Financing for Development

Female Genital Operations

Term coined by Joseph Wresinski to describe those living and extreme poverty and social exclusion in both North and South

Global Call to Action against Poverty

Gross Domestic Product

Term used by the UN to describe industrialised donor countries

Term used by the UN to describe 'developing' countries

International Non-Governmental Organisation

Membership Based Organisations of the Poor

Millennium Development Goals

New International Economic Order

Non-Governmental Organisation

Official Development Assistance

Poverty Reduction Strategy Papers

United Nations

United Nations Conference on Trade and Development

United Nations Development Programme

United Nations Children's Fund

United Nations Non-Governmental Liaison Service

United Nations Secretary General

Women's Environment and Development Organisation

World Food Programme 


\begin{abstract}
Poverty is one of the most serious issues of our time, and the major seat of the poverty eradication discourse is at the United Nations. The term participation has increasingly featured in the high level poverty discourse in recent years, as well as in development practice. However, in contrast to other identity groups, such as women, indigenous people and people with disabilities, the participation of people living in poverty in high level UN processes is not given priority. They are not seen as an identity group in their own right, rather they are subsumed into others. Furthermore, any participation is assumed to be acceptably realised at the local level, with little priority placed on the facilitation of participation in transnational or global institutions such as the UN. NGOs are assumed to be able to represent the poor, a situation which is problematic and serves to further marginalise people living in poverty. As NGOs translate and represent, they effectively silence people living in poverty.

In the absence of the poor, perceptions held by the general public and by decision makers about the poor continue to hamper the debate and restrict possible solutions. Furthermore, the exclusionary statistics-dominated language of UN debate and procedural restrictions present barriers to people living in poverty being meaningfully involved in the poverty discourse. Additionally, the overuse of statistics in these debates serves to abstract and dehumanise the poor.

This thesis makes the normative argument that people living in poverty should have a place and space at the United Nations, as do other identity groups. Their participation represents an opportunity to force the debate beyond statistics, and expose the harsh realities of ongoing suffering resulting from the world's failure to act. Their testimony and input could provide an effective catalyst for mobilising political will. Drawing on critical theory, I argue that regular participation and testimony of the poor has the potential to pierce the political facade within which the powerful at the UN make decisions, with scant realisation of the often devastating consequences for the currently invisible poor. The conclusion drawn from this argument is that the poor must be allowed to be leaders of their own liberation and to reclaim their dignity.
\end{abstract}




\section{Table of Contents}

$\begin{array}{ll}\text { Introduction } & 6\end{array}$

1. Poverty, identity groups and representation 12

$\begin{array}{ll}\text { i. The poverty and development discourse } & 12\end{array}$

ii. The role of NGOs 15

iii. Identity Groups and participation at the United Nations level 19

iv. People living in poverty and participation at the United Nations level 24

V. NGOs and their perceived representation of the poor 29

vi. The United Nations idea of participation of the poor sits primarily at the local 34

2. Why is it important that people living in poverty participate at the UN level?

i. Local participation alone has limitations 41

ii. The abstraction of poverty and the importance of language 45

iii. Challenging perceptions about the poor $\quad 54$

iv. The power of testimony to prompt political will 59

v. The poor must be leaders of their own liberation and reclaim their dignity 62

Conclusion 
'The greatest misfortune of all is to know that you count for nothing, to the point where even your suffering is ignored.'

- Joseph Wresinski

\section{Introduction}

Poverty is undoubtedly one of the most serious issues of our time. 18 million people die from causes linked to extreme poverty every year. ${ }^{1}$ The aid and humanitarian sector raises and spends billions of dollars annually, and many people in both the Global North and South ${ }^{2}$ dig deep to support poverty eradication programmes. We are often told that these efforts are working - the world's standard of living is improving, wealth is increasing, and life expectancy is the highest ever. The Millennium Development Goals (MDGs), the key political framework for international efforts against poverty, are close to being met in certain countries. Political leaders frequently declare that ours is the first generation that can eradicate poverty, and the member states of the United Nations (UN) meet regularly to reassess efforts to reach the collectively agreed MDG targets to 'eradicate' extreme poverty and hunger. Many citizens of the Global North believe their governments are doing all they can to eradicate poverty. However, although surveys show that most US citizens believe that their government gives $20 \%$ of its federal budget in foreign aid every year, ${ }^{3}$ the real figure is less than half of the agreed $0.7 \%$ of GDP. In fact, only 5 Northern signatories to the MDGs have fulfilled this commitment, ${ }^{4}$ the world is still beset by extremely unfair trade, one third of humankind's 50,000 daily deaths are from preventable poverty related causes, ${ }^{5}$ and the income gap is growing, not shrinking. ${ }^{6}$ While governments call for an end to poverty through the fight against corruption and increased aid effectiveness - even implementing policies that restrict aid allocation unless certain

\footnotetext{
${ }^{1}$ Thomas Pogge, "The First United Nations Millennium Development Goal: a cause for celebration?" Journal of Human Development, Vol. 5, No. 3 (2004) p. 1

${ }^{2}$ There is some debate about the validity of the term developing countries. I prefer to use Global South to represent the developing countries, and Global North to represent industrialised.

3 Ben Somberg, "The World's Most Generous Misers: Tsunami reporting misrepresented U.S. giving," September/October 2005, www.fair.org/index.php?page=2676 , (accessed March 20, 2010)

${ }^{4}$ OECD, "Development aid rose in 2009 and most donors will meet 2010 aid targets" http://www.oecd.org/document/11/0,3343,en 264934487449815791111 1,00.html (accessed April 17, 2010)

${ }^{5}$ Pogge, "The First United Nations Millennium Development Goal." p.386

${ }^{6}$ Ibid. p. 388
} 
criteria are met $^{7}$ - domestic agricultural subsidies in the Global North remain three times higher than Official Development Assistance (ODA). ${ }^{8}$ Furthermore, major natural catastrophes like the 2010 earthquake in Haiti re-ignite the ongoing debate about the usefulness of development aid. Many publicly ask why, after years of international intervention in such countries, are people of the South still so poor? Many wonder aloud whether aid dollars are being spent in the best way, suspecting corruption, greed, or inefficiency. Despite increasing international rhetoric regarding poverty, effective action towards the eradication of poverty remains negligible as the powerful resist making sacrifices at the domestic level.

The issue of poverty has been long discussed in a variety of fora, but in this generation, I suggest that the major seat of discourse is at the UN. This inter-governmental body, whose charter explicitly states as a goal the 'economic and social advancement of all peoples, ${ }^{\prime 9}$ serves as a high profile space for poverty eradication policy and decision making at the international level. The United Nations' MDGs set the current framework for global partnership in efforts to eradicate poverty. Numerous resolutions, public commitments, and efforts to alleviate poverty are channelled through the United Nations system. Several departments of the UN secretariat have poverty issues as part of their mandate and various funds and agencies are charged with alleviating poverty. Several committees of the General Assembly deal with the issue of poverty, such as the Second Committee through such resolutions as the biannual resolution on the Decade for the Eradication of Poverty, and the Third Committee through the framing of poverty as a human rights issue. ${ }^{10}$ Within the Economic and Social Council, (ECOSOC) the Commission for Social Development has as its core function the consideration of the three pillars of poverty eradication, full employment and social integration, as laid out during the 1995 Copenhagen Summit for Social Development. This landmark event asserted the need for people-centred development. ${ }^{11}$ World leaders frequently meet at various United Nations Summits to discuss, review, renew or recommit to poverty eradication and to various agreements, most notably the MDGs. Hundreds of non-governmental organisations (NGOs) have

\footnotetext{
${ }^{7}$ The US government's Millennium Challenge Account lists among its core criteria the need to 'demonstrate a commitment to policies that promote political and economic freedom... and control of corruption.' http://www.mcc.gov/mcc/selection/index.shtml, (accessed March 19. 2010)

${ }^{8}$ MDGMonitor, "Developed countries' subsidies to domestic agriculture are still more than three times higher than their Official Development Assistance." http://www.mdgmonitor.org/goal8.cfm (accessed April 17, 2010)

9 Charter of the United Nations and Statute of the International Court of Justice, (1945), http://www.un.org/en/documents/charter/, (accessed March 19, 2010) Preamble

${ }^{10}$ The Third committee considers a biennial resolution on extreme poverty and human rights. In 2009, it was A/RES/63/175

${ }^{11}$ World Summit for Social Development, Copenhagen, http://www.un.org/esa/socdev/wssd/textversion/index.html (accessed March 19, 2010)
} 
full-time staff at the United Nations Headquarters to intervene in the debates on poverty issues, and have considerable influence on UN processes. I therefore suggest that the issue of the poverty is entrenched at the United Nations, and that the UN serves as the core space for the development of poverty eradication policy. However, people living in poverty themselves are notable for their absence in spite of increasing rhetoric around the importance of participation of key stakeholders.

The term participation has increasingly featured in the high level poverty discourse in recent years, as well as in development practice. ${ }^{12}$ I suggest that in spite of a widespread recognition of the importance of the participation of people living in poverty in efforts to eradicate poverty, this is assumed to be acceptably realised at the local level, with little priority placed on the facilitation of participation in transnational or global institutions such as the UN. Governments are arguably increasing efforts to include their poor populations as actors rather than subjects of their poverty eradication initiatives. The advent of the Poverty Reduction Strategy Papers (PRSPs) and increasing support for such participatory initiatives as micro-credit and co-operatives affirms this trend. ${ }^{13}$ At the international policy level however, such participation has not been realised. Although some NGOs have long advocated for participation and consultation with people living in poverty at the international level as well as locally, I argue that the voices of the poor are almost always seen to be validly represented by NGO delegates, frequently from non-poor backgrounds, rather than people living in poverty themselves. An increasing push to include delegates from the Global South doesn't necessarily mean that the delegates will have an experience of poverty. Southern NGOs often resemble their Northern counterparts in terms of organisational and hierarchical structure, and representative staff have more in common with NGO staff from the North than the poor of the South. ${ }^{14}$ Despite the efforts of a handful of NGOs to make space for the participation of people with experience of poverty in UN processes and debates, the assumption that the poor are well represented by NGOs is pervasive, and, I suggest, problematic for the efforts to eradicate poverty. Such exclusion of the experiences and opinions of people living in poverty means that the poverty eradication discourse is framed without them. Discourse is powerful, and the language of a discourse is not used to not merely name the world; it divides it into groupings reproducing relations of power. ${ }^{15}$ Without people living in poverty genuinely participating in the discourse that leads to the

\footnotetext{
${ }^{12}$ Giles Mohan and Kristian Stokke, "Participatory Development and Empowerment: The Dangers of Localism" Third World Quarterly, Vol. 21, No. 2 (2000)p. 247

${ }^{13}$ United Nations Social Perspective on Development Branch, www.un.org/esa/socdev/social/intldays/IntlCoops/ (accessed March 22, 2010)

${ }^{14}$ As noted by Warren Nyamugasira, "NGOs and Advocacy: how well are the poor represented?", Development in Practice, Vol 8, Issue 3 (1998), and Nick Dearden "From charity to solidarity", Globalizations, Vol. 3, Issue 2, (2006)

${ }^{15}$ Jenny Edkins, Trauma and the Memory of Politics, (Cambridge: Cambridge University Press, 2003) p. 7 and 11
} 
development of poverty eradication policy, these policies are more likely to reproduce the status quo than benefit the poorest members of society.

The issue of poverty is the subject of many reports, analysis, debate and resolutions. However, the experiences of those living in poverty are often not reflected in high level policy documents or economic reports. For UN staff, poverty and development experts, government representatives, and NGOs, the use of an expert language grounded in statistics has become the prevailing way to discuss poverty. In contrast, a reduction in the percentage of people living within the World Bank definition of extreme poverty has little impact upon those for whom poverty persists. What is unseen to most experts in the field of poverty is the story of real people - the mother who goes to the rubbish dump every day to work so her children can go to school; the father who walks the streets looking for work so he can bring home food to his family; the woman who refuses to be re-housed out of her cemetery home because she cannot bear to have a better life while others are left behind. While the United Nations declares an International Year, Day, or Decade for the Eradication of Poverty, spend hours in meetings to negotiate minutiae of text for UN resolutions, and its member states regularly commit and re-commit to fund poverty eradication programmes, the poor work to survive. They are all too often unseen, unrecognised, and I suggest most importantly and detrimentally, unheard.

NGOs are culpable participants in this dynamic of exclusion. They encourage people to make regular symbolic gestures against poverty, and millions do. They demand action. They declare that they stand in solidarity with their brothers and sisters in the developing world, and implement aid projects that aim to empower and improve lives. They have a constant and visible presence in UN debates and decision making, taking advantage of their (hard fought for) place in the debate. They use their experiences working with the poor to attempt to improve policy and to put political pressure on the decision makers. As representatives of a global civil society, NGOs work to ensure that governments make decisions that improve the lives of the poor, especially women and children in developing countries. However, NGOs rarely fight to ensure that the poor represent themselves at the UN debates. Instead they more often act as a conduit for locally sourced - and therefore 'valid' views in high level debates.

One impediment to the participation of the poor in these debates is that the community of the poor are not seen as an identity group in their own right. This contrasts with recognised groups such as women, people with disabilities, indigenous persons, and others who have had their right to participation recognised at the UN level. In fact, one of the core priorities of major identity groups present at the UN is that people who identify with those groups are able to participate in UN debates. This has had some success at the United Nations, with many now seen as crucial actors in 
the development of these agreements, and representatives expected to be at the table when reviews and evaluations are carried out. This is not the case for people living in poverty. While it would now be unthinkable for most other 'key stakeholders' to be absent from discussions around issues that affect them (an outcome of much hard work over many years) the poor are frequently subsumed into these other interest groups.

In this thesis I therefore suggest that the poor are either absent altogether, have a token presence, or are deemed to be adequately represented by NGOs at the United Nations. Furthermore, and despite their best intentions, NGOs often block out the poor by attempting to represent the views of this community. They fill the space at the table in which the poor could sit. They translate and represent, and in doing so they silence. I suggest that the absence of people living in poverty exacerbates their marginalisation and compounds the oppressive nature of poverty. Furthermore, this marginalisation represents a missed opportunity to force the debate beyond statistics, and expose the harsh realities of ongoing suffering resulting from the world's failure to act. Seizing this opportunity could provide an effective catalyst for mobilising political will, and to partially fulfil a fundamental human right of participation. This thesis argues, therefore, that the participation of people living in poverty in the debates and processes of the United Nations - at both the local and international level - is a crucial step towards the eradication of extreme poverty. Their ongoing and meaningful presence at the United Nations could force the powerful to finally see the poor in all of their humanity, and make continued inaction untenable.

As this thesis emphasises the validity of personal testimony and the importance of communicating lived experience, it is fitting to provide a sense of my own background within the field of poverty eradication. I spent several years, from 2004 to 2008, as an NGO representative to the United Nations in New York, with a mandate to find space for people living in poverty - from the global north and south - to speak for themselves, as well as for their families and communities. I encountered numerous barriers to the success of this mandate, including what I perceived to be prejudice, lip-service, and tokenism, as well as a resistance by many of the incumbent participants to the sharing of their policy space. Taking a broadly critical theoretical approach, and using the reflections of theorists such as Paolo Freire, Joseph Wresinski, Jenny Edkins and Slavoj Žižek, and the substantial literature on poverty and participation, together with my own experience making space for and accompanying people living in poverty to speak at the United Nations, this thesis will make the normative argument that people living in poverty should have a voice at the highest level of policy making. This thesis does not have the space to define this participation or to examine the inherent challenges in detail. Rather I ask the reader to use as a guide the (imperfect, but 
institutionalised) type of participation now enjoyed by other identity groups, in particular women, people with disabilities and indigenous persons.

This thesis is divided into two parts. In part one, I present an overview of the poverty discourse at the United Nations, including the role of NGOs, the experiences of other identity groups and the lack of recognition of the poor as an identity group. I argue that the UN sees NGOs as valid representatives of the poor in high level debates, and has sought to address criticism of the predominance of Northern NGOs through an increased inclusion of NGOs from the south. However, this does not ensure participation of the poor themselves, rather it potentially 'whitewashes,' tokenises and further marginalises the poor. At the United Nations, local participation of the poor is seen as enough, whereas this is not the case for other identity groups.

In the second part of this thesis, I argue that this localisation of participation is problematic, and that the perceptions held by the general public and by decision makers about the poor hamper the debate and restrict possible solutions. Furthermore, I argue that the dominant language of UN debate, procedural realities, as well as the perceptions of the poor that are held by elites exclude them from being meaningfully involved. Additionally the overuse of statistics in these debates serves to abstract and dehumanise them. Finally, drawing on critical theory, I argue that regular participation and testimony of the poor has the potential to pierce the fragile facade within which the powerful at the UN make decisions, with scant realisation of the often devastating consequences for the often invisible poor. The conclusion drawn from this argument is that the poor must be allowed to be leaders of their own liberation and to reclaim their dignity. 


\section{Poverty, identity groups and representation}

The question of poverty, identity groups and representation has been the subject of much academic literature, and many identity groups have successfully fought for a space and voice at the United Nations. However, the poor are often assumed to be included in other identity groups, and thus already present, or alternately seen as validly represented by NGOs. In this section I argue that the influence of NGOs in the current poverty discourse reproduces the marginalisation of the poor, and that the UN sees participation of the poor as adequately realised at the local level. I begin by giving an overview of the poverty and development discourse.

\section{i. The poverty and development discourse}

The discourse around development and aid remains a highly contested space. Currently, the main seat of this discourse is at the United Nations, with the seed of a global fight against poverty planted in the UN Charter. It contains the goal of achieving 'international co-operation in solving international problems of an economic, social, cultural, or humanitarian character, and in promoting and encouraging respect for human rights and for fundamental freedoms for all...' ${ }^{16}$ Furthermore, the founding Member States agreed to pursue 'solutions of international economic, social, health, and related problems. ${ }^{17}$ How these goals are to be achieved remains the subject of much debate.

In the post-colonial era, the rapidly rising number of sovereign states required a new way of coexisting in the international sphere. ${ }^{18}$ Thus, the institutionalisation of foreign aid was motivated by politics - power, strategic interests and the possibility of long-term economic benefits to the powerful nations as opposed to a purely humanitarian rationale. Writers such as Tomohisa Hattori note that although the rhetoric was cloaked in moral imperatives, a purely moral motivation for aid does not hold up to scrutiny. Hattori suggests that these motivations may be analysed differently by various competing theories of international relations: Realists emphasise cold war era strategic interests; Liberals focus on increasing global prosperity through international trade and the market;

\footnotetext{
${ }^{16}$ Charter of the United Nations and Statute of the International Court of Justice, Chapter 1, Article 1 (3)

${ }^{17}$ Ibid. Chapter 9, Article 55 (b)

${ }^{18}$ S C Dube, Modernization and Development: the Search for Alternative Paradigms, (London: Zed Books, 1988) p. 15
} 
while World System theorists see aid as a smokescreen and method of reproducing the exploitation and economic domination of the peripheral states by those of the core. ${ }^{19}$

Tied to the idea of poverty alleviation was that of development. Tapping into the hopes for future prosperity of the citizens of newly independent states, 'modernisation' became the dominant theory of development in the early post-colonial era, offering a possibility of prosperity for all. However, many theorists have noted problems with the Modernisation paradigm. For instance, S.C. Dube recognised in the early 1980 s that:

pockets of endemic poverty persist even in the most developed societies. Violence continues to increase and the erosion of moral values no longer causes revulsion. Corruption has become a way of life and is being rationalised. If these are necessary and inevitable aspects of modernisation, the Third World would rather avoid it; but this is easier said than done. ${ }^{20}$

Despite competing theories of development, the focus of the development project was predominantly on economic rather than social development. By the 1980s, this focus was reinvigorated by a growing free market orthodoxy, which emphasised the neo-liberal economic paradigm as the underpinning principle of the development discourse. This was manifested through the Structural Adjustment Policies of the International Financial Institutions.

The 1990s saw an opening up of the discourse towards human security as non-Western thinkers such as Armatya Sen and Mahbub ul Haq contributed to the debate. The 1994 UNDP Human Development Report called for the redefinition of security as human security, or rather, ' $a$ concern with human life and dignity, ${ }^{21}$ an analysis which recognised human security as a multifaceted, complicated concept, only partly concerning economic factors. They argued that any examination of human security should take into account the interdependent daily concerns of ordinary people, including challenges of food security, the chance to work and provide for one's family, access to education for children, and the opportunity for good health and freedom from violence. The report notes that these are concerns which are universal, present in North and South, and are frequently affected by international factors. ${ }^{22}$

After the major conferences and summits of the 1990s, the UN staked its place as a dominant space for the discourse around poverty eradication, as the only global mechanism for bringing the

\footnotetext{
${ }^{19}$ Tomohisa Hattori, 'The Moral Politics of Foreign Aid' Review of International Studies, Vol. 29, no 2 (April 2003) p. 230

${ }^{20}$ S C Dube, Modernization and Development, p. 11

${ }^{21}$ United Nations Development Programme, Human Development Report (United Nations: 1994), p. 22

22 Ibid. p. 22
} 
world's nations together - theoretically as equal sovereign states. Although based on a principle of equal sovereignty, economic inequality between the member states of the United Nations has always been and remains stark. As the UN worked towards the goal of self-determination of the world's peoples, and former colonies became independent and sought prosperity for their citizens, the UN was called upon to redress the global systematic and structural imbalances in accordance with its previously stated goals. ${ }^{23}$ In 1964, concern among developing countries about the fairness (or otherwise) of the international economic system saw the positing of a New Economic International Order (NIEO) which led to the establishment of the United Nations Conference on Trade and Development (UNCTAD). This organisation remains active in promoting the discussion of these issues using the Global South perspective. Today, many sections of the UN family address poverty issues, including the Department of Economic and Social Affairs, the Millennium Campaign, the United Nations Development Programme (UNDP), the Food and Agricultural Organisation (FAO), the United Nations Children's Fund (UNICEF), and the World Food Programme (WFP).

In 1996, at the launch of the First International Decade for the Eradication of Poverty, Member States of the United Nations declared that 'eradicating poverty is an ethical, social, political and economic imperative of humankind.' ${ }^{24}$ At the launch of the Second Decade for the Eradication of Poverty in 2008, they reiterated that 'eradicating poverty is the greatest global challenge facing the world today. ${ }^{25}$ In 2000, 189 UN Member States committed to 'making the right to development a reality for everyone and to freeing the entire human race from want,' resolving to 'create an environment - at the national and global levels alike - which is conducive to development and to the elimination of poverty. ${ }^{26}$ The subsequent Millennium Development Goals named as its first goal the eradication of extreme poverty and hunger, with the target to 'halve, between 1990 and 2015, the proportion of people whose income is less than $\$ 1$ a day'. ${ }^{27}$ Industrialised governments committed $0.7 \%$ of GDP towards Official Development Assistance (ODA) to work towards that goal, in an effort to realise its stated commitment to '...spare no effort to free our fellow men, women and children from the abject and dehumanizing conditions of extreme poverty, to which more than a billion of them are currently subjected. ${ }^{28} \mathrm{~A}$ raft of Non-Governmental Organisations (NGOs) are frequently

\footnotetext{
${ }^{23}$ Charter of the United Nations and Statute of the International Court of Justice, Preamble

${ }^{24}$ United Nations General Assembly Resolution, First United Nations Decade for the Eradication of Poverty, A/RES/51/178

${ }^{25}$ United Nations General Assembly Resolution, Second United Nations Decade for the Eradication of Poverty (2008-2017) A/RES/62/205

${ }^{26}$ United Nations General Assembly Resolution, Millennium Declaration, A/RES/55/2, para. 12

${ }^{27}$ United Nations Millennium Development Goals, http://www.un.org/millenniumgoals/poverty.shtml (accessed April 18, 2010)

${ }^{28}$ United Nations Millennium Declaration, para. 11
} 
called upon by the UN to assist in fulfilling these commitments, and in fact, are more often than not, the implementers of such commitments and policies. ${ }^{29}$ They recognise the importance of interacting with the United Nations to affect change at the international level.

\section{ii. The role of NGOs}

Never before have so many actors worked at an international level in the fight against poverty. Government funded ODA and an increasing number of multinational and grassroots NGOs are part of a multi-billion dollar a year development industry and there are frequent partnerships between NGOs, international institutions, and governments. Poverty is regularly entering the mainstream public consciousness, with high profile economists engaging in public internet debates about the efficacy of aid, and celebrities and ordinary citizens engaging with the discussion. ${ }^{30}$

It is often stated that NGOs are at the front line of efforts to fulfil the commitments around poverty eradication. Many poverty eradication projects by the various funds and agencies - for example the UNDP and UNICEF - are implemented on the ground in partnership with NGOs, ${ }^{31}$ and for many donor countries, a large proportion of their ODA is channelled through NGOs. This gives NGOs a particularly informed perspective on the efficacy of development efforts and as a result, they are often invited to share this expertise at the policy level. Many NGOs commit significant resources in order participate at the UN, which has recognised their expertise formally through a process of registration, and the awarding of formal consultative status. Therefore, the dominant actors in the poverty discourse and practical programmes are the United Nations; through its secretariat, agencies and funds; governments, who fund initiatives through ODA and who design and implement projects through their national activities including PRSPs, and NGOs who both carry out poverty eradication projects and use their experience to affect policy at the national and international level. The impact of NGOs on UN processes has led to them being termed the third UN, along with Governments and the Secretariat. ${ }^{32}$ However, NGOs infrequently use their influence and position to ensure that the poor are present to represent themselves.

\footnotetext{
${ }^{29}$ Thomas Weiss et al, "The 'Third' United Nations”, Global Governance, Vol. 15 (2009) p. 130

30 William Easterly and Jeffrey Sachs have had a series of often passionate debates online http://www.nyu.edu/fas/institute/dri/Easterly/SachsDebates.htm (accessed March 28, 2010)

${ }^{31}$ Weiss et al, "The Third United Nations" p. 130

32 Ibid. p. 123
} 
There are various types of NGO affiliations with the UN. NGOs can acquire general, special or roster consultative status through the UN Economic and Social Council which entitles them to participate in debates, albeit under strict rules and constraints, and submit written formal interventions which are distributed to member states and recorded as part of the formal proceedings. ${ }^{33}$ The smaller NGOs frequently lack a permanent presence in Geneva or New York and travel in an ad hoc manner to participate in relevant UN meetings. However, the larger NGOs have permanent, full-time representation, some with office resources and staffing levels that tower over the smaller member states. There is certainly a predominance of NGOs from the North participating in UN processes: in 2009, 33\% of NGO representatives participating in United Nations meetings were from North America, with the second largest group (23\%)coming from Europe. ${ }^{34}$ As of 2010 there were 3,052 NGOs holding consultative status with the United Nations; a marked increase from the original 41 that were granted status at the establishment of the UN - NGO formal relationship in $1946 .{ }^{35}$ Recent UN reports emphasise the importance of member states and the UN system working with Civil Society. The UN appoints NGO focal points in most Secretariat departments, and the UN Non-Governmental Liaison Service (UN-NGLS), which is funded by various UN departments ${ }^{36}$ and several governments, ${ }^{37}$ also works to facilitate NGO relationships with the various parts of the UN.

However, NGOs often have to re-assert their right to contribute substantively to UN processes, and the relationship between the UN and NGOs is often challenging. The high profile Cardoso Report of 2004 noted that for many, 'the United Nations remains rather opaque, uncommunicative, poorly informed about local civil society dynamics and unwilling to consult or engage except to recruit implementing partners after strategies have been agreed upon. ${ }^{38}$ Yet the same report, commissioned by the UN Secretary General to reflect upon the changing nature of UN and Civil Society relations, also noted the crucial role of the United Nations as 'the convener, facilitator and provider of a "safe space" for actors to debate and decide on courses of action for reaching global

\footnotetext{
${ }^{33}$ United Nations Department of Economic and Social Affairs NGO Branch, http://esango.un.org/paperless/Web?page=static\&content=apply (accessed April 17, 2010)

${ }^{34}$ United Nations CSO Net Civil Society Network, Civil Society Participation Statistics 2009, http://esango.un.org/irene/index.html?page=static\&content=stats (accessed April 18, 2010)
}

35 United Nations Department of Economic and Social Affairs NGO Branch, http://www.un.org/esa/coordination/ngo/ (accessed March 17, 2010)

${ }^{36}$ United Nations Department of Economic and Social Affairs, United Nations Conference on Trade and Development, the World Health Organisation, and the World Food Programme. Information taken from www.un-ngls.org (accessed February 5, 2010)

${ }^{37}$ Including Canada, France, Netherlands, Spain, Switzerland and Norway http://www.un-ngls.org/spip.php?page=article s\&id article=704, (accessed February 5, 2010)

${ }^{38}$ United Nations Cardoso Report: 'We the peoples: civil society, the United Nations and global governance Report of the Panel of Eminent Persons on United Nations-Civil Society Relations', A/RES/58/817, (2004) para 83, p. 41 
targets. $^{39}$ Meanwhile, NGOs continue to invest in the United Nations as the major seat of poverty discourse.

Arguably the main context for NGO advocacy concerning poverty in the last decade is that of the MDGs. ${ }^{40}$ Although much of the promised action and funding towards the MDGs has not been forthcoming, the rhetoric is still strong and governments are facing pressure from their citizens, mobilised by international NGO coalitions such as the Global Call to Action against Poverty (GCAP), and the Millennium Campaign, which is a member of the UN system. Many NGOs also work on crosscutting issues that affect the success of the MDGs, such as unfair trade rules, developing country debt, gender, and climate change.

The NGOs that have a presence at the UN come in all shapes and sizes and differ markedly according to their history, funding, country of origin, perspective, focus, organisational structure, mission, reputation and credibility, expertise and constituency. They range from social movements that are organised and run by their constituents, through to multi-national organisations that operate much like corporations, i.e. with a centralised management system, a strong hierarchy, and professional staff. They are able to influence the development of reports, policy and UN resolutions directly at the UN, although some do so more effectively than others. For instance, the Cardoso report noted the generally recognised 'imbalance between the voices of Northern and Southern actors in international policy forums, ${ }^{41}$ and the importance of involving NGOs from both North and South. It also emphasised that

...policy-making can be more effective when all parties are on board, particularly across the North-South divide. This is not just about tapping different capacities - it is about exchanging perspectives, building respect for different types of experience and knowledge and recognizing the power of diversity, the power of gender, region and culture. ${ }^{42}$

However, the report mainly recommended this strengthening of UN interaction with civil society at the country as opposed to the international level.

The Cardoso report also suggested that the UN look beyond the prevalent international development NGOs and broaden the range of groups and organisations able to intervene in UN meetings. In recent years this recommendation has been adopted, and a variety of stakeholders are

\footnotetext{
${ }^{39}$ Cardoso Report, p.38, para 71

${ }^{40}$ United Nations Millennium Development Goals http://www.un.org/millenniumgoals/, (accessed February 19, 2010)

${ }^{41}$ Cardoso Report, p. 29, para. 35

${ }^{42}$ Ibid. p. 29, para. 32
} 
often able to register as observers at events without being affiliated with an NGO that has consultative status. However, such changes do not necessarily make it easier for people living in poverty to contribute, because for such vulnerable groups to participate they usually require the support of an NGO. The report noted this difficulty, highlighting the possible misuse of the term 'partnership', which implies an equality between the parties that is rarely realised. It suggested that actors from the Global South often felt disadvantaged because they lacked the access to networks, information and resources more readily accessible to the larger Northern-based organisations. ${ }^{43}$ It is a frequent refrain amongst Southern NGOs that those from the North are able to monopolise access to Northern-situated institutions such as the UN. ${ }^{44}$ Warren Nyamugasira urges that Southern NGOs must also 'be afforded unrestricted access into these enclaves of power so that they can engage with the relevant actors directly. Ultimately, the people must represent themselves... ${ }^{45}$

The Cardoso report also made concrete suggestions for a different way at looking at participation, including

small, informal, high-level roundtable forums to allow real exchanges of experience and avoid entrenched positions. Participants would be world specialists, leaders of communities most directly affected and ministers or top officials from a range of countries. They would inform and be informed by global public opinion and experience. ${ }^{46}$

However, it is important to note that this list of possible participants does not include the poor themselves - the closest it comes to suggesting their inclusion is to mention leaders of affected communities. I suggest that there is an assumption that the poor are able to be represented by NGOs from the South and have the ability to participate in their local communities. This leads to a blurring of geographical origins and poverty status which is, in effect, is a false consciousness - that the participation of the poor can be realised by the participation of Southern NGOs, or at the local level. This thesis argues that neither of these forms of participation is, by itself, true participation of the poor and that this exclusion results in further marginalisation of people living in poverty.

\footnotetext{
${ }^{43}$ Ibid. p. 37

${ }^{44}$ Warren Nyamugasira, "NGOs and Advocacy: how well are the poor represented?" Development in Practice, Vol 8 Iss 3 (1998) p 303

${ }^{45}$ Ibid. p. 303

${ }^{46}$ Cardoso Report, p. 32, para. 46
} 


\section{iii. Identity groups and participation at the United Nations level}

Many UN events and conferences now recognise the importance of stakeholder participation. Identity groups have worked for decades in order to be recognised by the United Nations as essential stakeholders and necessary participants in the debates that concern them. There are numerous examples of this, some of which I will highlight below.

People with disabilities were intimately and actively involved at all levels in the process leading to the 2006 Convention on the Rights of Persons with Disabilities. Working under the slogan 'nothing about us without us,' a coalition of persons with disabilities organised on an international scale and was integral to the development of the Convention. ${ }^{47}$ The process is often held up as an example of best practice in terms of participation, with Arlene Kanter suggesting that the ad hoc committee process was the most inclusive in the history of the UN. ${ }^{48}$ Extensive effort was made to ensure the participation of people with disabilities, including practical changes to the UN buildings, such as the installation of ramps. ${ }^{49}$

Similarly, indigenous people played a crucial role in the drafting and adoption of the Declaration on the Rights of Indigenous Peoples that was passed in 2008 after two decades of effort. Claire Charters notes the importance and validity of this participation, finding that 'the ultimate Chair of the Working Group on the Draft Declaration submitted a text... that reflected both consensus and compromise provisions between indigenous peoples and states. ${ }^{50}$ She also found that before being presented to the UN General Assembly for a vote of adoption, the text was given final approval by representatives of indigenous groups who were present at the UN. This recognition of the importance of the participation of such groups is reinforced by the enduring structure of the Permanent Forum on Indigenous Issues, which has indigenous people from each region sitting on its organisational bureau on an equal footing with Governments. ${ }^{51}$

\footnotetext{
${ }^{47}$ Arlene Kanter, "The Promise and Challenge of the United Nations Convention on the Rights of Persons with Disabilities," Syracuse Journal of International Law and Commerce, Vol. 34 (2007) p. 308

48 Ibid. p. 294

49 lbid. p. 297

${ }^{50}$ Claire Charters, "A Self-Determination Approach to Justifying Indigenous Peoples' Participation in International Law and Policy Making", (Paper Presented at 'We the People(s): Engagement and Participation in Government Conference, Wellington 11 - 12 February 2010)

${ }^{51}$ United Nations Permanent Indigenous on Issues, http://www.un.org/esa/socdev/unpfii/en/structure.html (accessed April 17, 2010)
} 
Finally, women have been considered essential actors in policy making since the proliferation of major conferences ${ }^{52}$ of the $1990 \mathrm{~s}^{53}$ The UN system now recognises the importance of women participating in decision-making at the international and national level, and has requested governments to ensure men and women are equally represented in all conferences, committees, and international bodies. ${ }^{54}$ The annual ECOSOC Commission on the Status of Women (CSW) sees an influx of women from many countries, staking their place at the podium and intervening in a variety of discussions and debates at the United Nations. At the first meeting of the CSW in 1946, all fifteen government delegates were women ${ }^{55}$ and in the present day, both the government and NGO delegations participating in the CSW are dominated by women. In fact, the majority of NGO delegates participating in all UN meetings are women, representing $61 \%$ of the total. ${ }^{56}$

I suggest, however, that the importance placed on participation of women at the UN does not extend to a serious reflection on the 'type' of women present. This occurs despite NGOs frequently citing the predominance of women among the ranks of the poor as evidence for the importance of women's participation in UN processes. I suggest that there is still a substantive absence of women with experience of poverty at such events, in spite of recent allusions to the importance of participation of women from the Global South. This is what I refer to as the failure to use background as a criterion for participation. An illustrative example is the reaction to the recent appointment of a High Level Advisory Board on Climate Change Financing by the UN Secretary General. In March 2010, a campaign was launched by the Women's Environment and Development Organisation, (WEDO) urging the Secretary General to include a woman on the panel. ${ }^{57}$ Arguments justifying the need for a female member included that '(w)omen still make up the poorest of the poor, have unequal access to land, loans, education and resources, and are underrepresented in decision-making bodies' ${ }^{58}$ and crucially that ' $(w)$ omen and men feel the impacts of climate change differently, and women and men both have capacities, expertise and roles to play in responding to

\footnotetext{
52 Such as the United Nations Conference on Environment and Development (1992, Rio de Janeiro), World Summit for Social Development (1995, Copenhagen) and Fourth world Conference on Women (1995, Beijing)

53 Torild Skard, "Gender in the Malestream - Acceptance of Women and Gender Equality in Different United Nations Organisations," Forum for Development Studies, Vol. 36, Iss. 1 (2009) p. 165

${ }^{54}$ Ibid. p. 165

${ }^{55}$ United Nations Division for the Advancement of Women, 'Short History of the Commission on the Status of Women' http://www.un.org/womenwatch/daw/csw/index.html\#about (accessed March 15 2010)

${ }^{56}$ United Nations Civil Society Network, Civil Society Participation Statistics, 2009 http://esango.un.org/irene/index.html?page=static\&content=stats (accessed April 18, 2010)

57 WEDO http://www.wedo.org/learn/campaigns/climatechange/join-wedo-in-urging-un-secretary-generalban-ki-moon-to-appoint-women-to-the-high-level-advisory-group-on-climate-change-financing (accessed March 15 2010)

${ }^{58}$ WEDO http://www.wedo.org/wp-content/uploads/Open-Letter-to-UN-SG.pdf (accessed March 15 2010)
} 
the threats of climate change effectively and efficiently. ${ }^{, 59}$ There is a clear suggestion that only a woman can represent the experiences of women. However, WEDO did not nominate a woman with experience of the poverty, despite it being a central justification for the campaign. Instead, the 11 suggestions included Heads of State, economists, UN Under-Secretary Generals, and senators. The nominees appear to have been selected based on their expertise or status, with gender rather than their background being the key factor. Again, the poor were not consciously sought out to participate.

It is clear that UN member states consider the participation of key stakeholders in all of the aforementioned groups important, and that they recognise them as necessarily part of each stage of the decision making process of the UN. Many of these 'identity groups' include a disproportionate number of people living in poverty and are frequently mentioned in literature and resolutions about poverty. It is often noted that 'persons with disabilities are disproportionately represented among the world's poor. ${ }^{160}$ Similarly, there are frequent references to the 'widespread feminization of poverty ${ }^{61}$ and many resolutions that deal with poverty include phrases such as 'especially women. ${ }^{62}$ ECOSOC debates often focus on key groups, noting, in 2007, that 'decent jobs, especially for women and youth, provide the strongest link between economic growth and poverty reduction.' 63 Furthermore, the 2008 resolution extending the mandate of the Independent Expert on Extreme Poverty requests that she

pay particular attention to the situation and empowerment of women in extreme poverty, applying a gender perspective in his or her work (and) pay particular attention to children living in extreme poverty, as well as to the most vulnerable groups, including persons with disabilities who live in extreme poverty. ${ }^{64}$

However, these groups could not to be said to represent the totality of people experiencing poverty. Poverty also affects boys, able bodied people, non-indigenous, and men. The assumption that the participation of women, people with disabilities or indigenous populations in UN processes

${ }^{59} \mathrm{lbid}$.

60 United Nations Enable, 'Rights and Dignity of Persons with Disabilities,' http://www.un.org/disabilities/default.asp?id=33 (accessed March 15 2010)

${ }^{61}$ United Nations Commission for Social Development Report on the forty-fifth session (2007) p. 7 http://www.un.org/esa/socdev/csd/2007/documents/final-report-eng.pdf (accessed April 18, 2010)

${ }^{63}$ United Nations Department of Economic and Social Affairs, 'Strengthening Efforts to Eradicate Poverty and Hunger: Dialogues at the Economic and Social Council' http://www.un.org/en/ecosoc/docs/pdfs/07-49285ECOSOC-Book-2007.pdf (accessed 15 March 2010) p. 10

${ }^{64}$ United Nations Human Rights Council Resolution 8/11 Human rights and extreme poverty, (2h) 18 June 2008 (accessed April 18, 2010) 
also means that the poor are present, may therefore be a further, unrecognised, source of their omission. To most, 'the poorest comprise neither a class nor an identity grouping, and do not easily gain representation within either old or new movements. ${ }^{165}$ Such thinking has implications for the eradication of poverty, as the poor are bound to be frequently absent from consideration as decision makers focus on other groups.

In contrast, Joseph Wresinski understood the poor as a separate identity group, using the phrase 'Fourth World' to describe people who are marginalised and living in extreme poverty and social exclusion, whether in the North or South. Challenging the dominant focus on poverty in developing countries as being a result of a state-level economic poverty, Wresinski reminded us that poverty also exists in affluent countries. Taking a human rights approach, he noted that:

the world is not, as we had thought, divided into countries where human rights prevail and countries where they are less fully, or not yet, respected. The extreme poverty which has resurfaced in rich countries where its existence had been forgotten is now understood as a systematic violation of all fundamental human rights. There are therefore serious infringements of human rights in every country, which are not accidental but inherent in the way people organize their lives in the national and international community. ${ }^{66}$

Thus, Wresinski situates poverty alongside gender, disability and indigineity as the basis for forming a transnational identity group.

This clear positioning of the issue of poverty at the transnational rather than local, or even personal, level is a concept which I suggest is counter to the current discourse around poverty. Wresinski asserts that the very poor are a community, a people united by the similar challenges that they face due to their poverty, even if they are not often able to come together to recognise their commonalities. Speaking of his experience of living in a French emergency housing camp in the late 1950s, he described how the term Fourth World was coined by the residents, born of solidarity with others around the world who experienced the dehumanising reality of extreme poverty. 'The very poor revealed to me the day-to-day realities of life which unite them across cultures and continents and which mean that they all live as outlaws, everywhere.' 67 This focus on the exclusion,

\footnotetext{
${ }^{65}$ Sarah Bracking and Sam Hickey, "Exploring the Politics of Chronic Poverty: From Representation to a Politics of Justice?" World Development, Vol. 33, No. 6 (2005) p. 859

${ }^{66}$ Joseph Wresinski, "The Very Poor, Living Proof of the Indivisibility of Human Rights (1989), http://www.joseph-wresinski.org/THE-VERY-POOR-LIVING-PROOF-OF-THE.html (accessed April 18, 2010) p. 1 ${ }^{67}$ Ibid.
} 
dehumanisation and violation of human rights rather than an economic deficit is a way to understand the commonalities of the poor of all countries. Even though poverty may manifest itself in different ways in different countries and communities, and affect certain groups to a varying extent and in diverse ways, the core experiences are essentially the same - insecurity, exclusion and dehumanisation.

Furthermore, Wresinski described the poor as being forced to:

slip from an identity that is already negative to a kind of non-identity, an administrative non-existence, the disappearance from every register, every set of statistics. Human beings, whole families then take on the appearance of ghosts: they have been seen somewhere, but nobody remembers where exactly nor how many they were. For them it is the end of all hope of still being among those who once proclaimed themselves to be "we the peoples of the United Nations" that international community which chose the achievement of human rights as its ultimate goal. The loss of identity also sounds the death knell of any hope that, because one exists in the eyes of the world, one may join forces with others, in order to fight for ones rights together. The poorer people are, the more they are deprived of the right to inhabit the earth, and the more they need to join forces across continents. Yet, unfortunately, the poorer they are, the fewer rights they have, the less free they are to unite in common struggle. Without identity, they are deprived of a history of their own and excluded from the history of their people. They are prohibited from belonging to any group which, in the name of its past and present history, would have a common goal to pursue in the future. ${ }^{68}$

It is clear, therefore, that to focus only on the need for participation of women, people with disabilities, youth, and indigenous - even though they figure strongly in poverty statistics - is bound to leave the development of policies for the eradication of poverty wanting, further excluding those who are left out of such groupings.

\footnotetext{
${ }^{68}$ Ibid. p. 4
} 


\section{iv. People living in poverty and participation at the UN level}

People living in poverty face many barriers to participation at the United Nations including: lack of proactive inclusion by the organisers of Commissions, debates and events; challenging and/or exclusionary procedural norms; the perceived need to keep the debate objective and policy-focused - a difficulty for speakers who have an intense personal experience of the issue being discussed; and the perceptions held by decision makers about the poor.

The Commission for Social Development (CSocD) provides the main space for non-state actors to intervene in the discussion about poverty at the UN level. While it is considered necessary for relevant key stakeholders to be 'at the table' at other Commissions and events, the poor are considered differently and are striking in their absence in this forum. As the Commission for Social Development is a functional Commission of the Economic and Social Council, NGOs with formal consultative status are able to submit written interventions and to participate in the oral debate. They are also very active in the organisation of various side events ${ }^{69}$ on relevant topics. However, I suggest that the participation of people living in poverty is not seen as a priority by the UN Secretariat or bureau. There is no stated imperative - as is the case with other functional Commissions such as the Commission on the Status of Women - for the key stakeholders to participate, except through their representative NGOs. If people living in poverty attend and participate, it is usually initiated by a small number of NGOs, ${ }^{70}$ and confined to parallel events and the Civil Society Forum which, although held inside the UN building, are not part of the official programme of work.

I therefore suggest that the UN system and member states see the participation of NGOs as being a valid substitute for the participation of people living in poverty, in contrast with other identity groups. This results in a marginalisation and silencing of the poor. Furthermore, I have proposed that the lack of participation of people living in poverty is partly rooted in the failure to recognise people living in poverty as a 'people' or an identity group in their own right. Although Bracking and Hickey are speaking of the domestic level when they emphasis the political powerlessness of the poor because 'neither the poor nor the poorest are a specific political constituency; they constitute neither a class nor any other form of "identity" group based on shared

\footnotetext{
69 Increasingly referred to as parallel events by NGOs as a way to demonstrate the importance to the proceedings. Governments frequently attend such events which are organised by NGOs, with the support of the DESA NGO focal point and are generally held within the UN buildings.

${ }^{70}$ The NGO sub-committee for the eradication of poverty makes efforts each year to ensure representation of people living in poverty during the events they organise, such as the Civil Society Forum.
} 
territory or culture, ${ }^{, 71}$ at the international level, the consideration of the poor as an identity group is even more diluted.

There have been attempts in recent years to include the voice of Civil Society in High Level meetings in which participation is normally restricted to Member States. However, consistent with the perception that NGOs are representative of people of living in poverty, efforts to include alternative voices have generally focused on encouraging NGOs from the South, with limited consideration of their organisational structure or membership base. ${ }^{72}$ These perceptions play a significant role in whether the input of people with experience of the issue being discussed is heard, taken seriously, or disregarded. For example, when the 2005 High Level Plenary Meeting to review the implementation of the MDGs held informal hearings with Civil Society in June of that year, the UN General Assembly President established a 'Civil Society and Private Sector Task Force ${ }^{73}$ to assist in the selection of speakers and participants for the hearings. The hearings were held within the UN buildings and organised into four clusters, addressing the issues of security, poverty, dignity and UN reform, with most sessions featuring the cross-cutting issue of poverty and inequality. A number of representatives from UN member states were present at each hearing, and for many present in the room - including myself - an exchange between an NGO participant and member state representative served as a reminder of the often differing understandings and perceptions between the two groups.

Ms Alma Bulawan ${ }^{74}$ from the Philippines Coalition Against Trafficking in Women, participated in the hearings under the cluster titled 'Freedom from Fear.' Speaking towards the end of the session, she made a statement about the importance of good policy to combat trafficking and prostitution and the need for support for women who find themselves trapped in these circumstances. Speaking on behalf of her organisation, she noted that such activities were rooted in economic inequality and that most women caught in this situation faced a significant stigma, necessitating policy solutions to

\footnotetext{
${ }^{71}$ Bracking and Hickey, "Exploring the Politics of Chronic Poverty" p.857

${ }^{72}$ Although there is some reference to a concern about the exclusion of 'grassroots organizations, communitybased groups, NGOs in the Global South' being unaware of the hearings, as noted in the earlier point on the Cardoso report, organisational structure is often given less priority than geographical origin. (Millennium +5 NGO Network 'We Will Spare No Effort: A Civil Society Call to Action for the Five Year Review of the Millennium Summit and the Millennium Development Goals' June 2005, p. 11)

${ }^{73}$ United Nations Non-Governmental Liaison Service, 'Informal Interactive Hearings of the General Assembly with NGOs, civil society organizations and the private sector New York, 23-24 June 2005', http://www.un-ngls.org/orf/GA-hearings.htm (accessed March 20,2010)

74 Transcribed by the author from UN Webcast 'Informal Hearings of the General Assembly with nongovernmental organisations, civil society organisations and the private sector,' Freedom from Fear, 24 June, 2005, (approx. 2:29) http://www.un.org/ga/civilsocietyhearings/webcast.html (accessed March 15, 2010)
} 
enable them to reintegrate into society. Calling on the United Nations to 'address the trafficking and prostitution at the global and national level ${ }^{75}$ she requested that the UN undertake such initiatives as reintegration support and job opportunities. As she finished her statement - which clearly had a strong significance for her - she began to cry, managing at the end to highlight a 'collective hope for freedom from fear, freedom from violence and freedom from prostitution. ${ }^{76}$

Once Ms Bulawan had finished speaking, the meeting Chair invited government representatives to respond. The Representative of Chile began by noting that he was not reading from a prepared statement, and said, in part:

In a spirit of interactive debate I would like to express the feelings that I have felt during this morning's debate. It's important to bring the dimension of emotion into this building. I'm not saying it's always absent but it's perhaps not the better emotions that prevail in our debates and our discussions. Bringing emotion into multilateral work is a good antidote to the cynical attitude that stands just outside the door of every diplomat's office. If we were cynical we would look coldly at some of the topics that we see on our agendas and we would look on people's situations, families as just numbers, as statistics... But those children and their mothers have faces, they have names, they have feelings and they have lives... But the United Nations remains a political forum, and while it is true that in moments such as this, we have to experience emotion, we have to acknowledge it, we have to look at the raw reality as it is, the perception of the reality and its raw brutality is not enough. An intergovernmental political forum such as us can only handle what can be handled. Politics is the art of the possible. We organise our work, we focus it within rules of procedure, within a context, within systems with an insistence for human conviviality. Good neighbourliness is ruled by law and rules of behaviour whether this be states, societies, groups, families. Now, what am I getting at?

An intense therapy session is not enough to solve problems. Each and every one of us has to shoulder his or her share of responsibility. Non-governmental organisations also have their share of responsibility. And their responsibility is to help us... But this is something that has to be built and structured on something more than just emotion. We need concrete proposals. We need possible proposals. We need ideas that are important and that have to be addressed...

\footnotetext{
${ }^{75}$ Ibid

${ }^{76}$ Ibid
} 
So please never lose touch with your emotions, never lose touch with your sense of dedication, But please make sure that all the realism and pragmatism is there too so you actually get results. ${ }^{77}$

After a long session of fairly dry NGO statements, the speaker was clearly reacting to Ms. Bulawan's emotion, and I suggest that in his preoccupation with her passion, he failed to hear her wellprepared concrete policy suggestions.

The Representative of Cameroon had a rather different focus in responding shortly thereafter, stating that:

...human beings must remain at the centre of all our concerns. The Representative of Chile talked about emotion. He talked about it quite rightly and with very evocative words. Yes, emotion is necessary, emotion should be taken into account in the statement that we're working on towards this coming September. I think that the best image, the one that I will keep is the image of Miss Alma Bulawan just a few moments ago at the end of her statement, a statement she was really unable to finish, but I think that her message was one that can leave no one indifferent, a message that was heard by all. ${ }^{78}$

I argue that the understandable emotion present in the voice of Ms Bulawan affected the perception of her statement by these two decision-makers. For one, it seemed to be a barrier to his consideration of the policy recommendations, and for the other, it was a striking reminder of the seriousness of the issue. Although hers was not a direct testimony, her obvious connection to the issue significantly impacted the way her statement was perceived by the policy makers that were present.

An additional barrier to genuine participation of people with experience of poverty lies in procedural preferences. During his opening statement, the chair of the Civil Society Hearings requested that the participants avoid reading from scripts, but rather react and respond to other speakers. ${ }^{79}$ While this kind of interactive and spontaneous debate would be preferable, it is in direct contrast to the standard UN debates in which government representatives read lengthy prepared statements that usually fail to have any connection to the previous speakers. For non-professionals such as people living in poverty, this requirement can be overwhelming as people living in poverty

\footnotetext{
${ }^{77}$ Ibid. emphasis mine (accessed March 15, 2010)

${ }^{78} \mathrm{Ibid}$.

${ }^{79}$ Transcribed by the author, United Nations Webcast 'Informal Hearings of the General Assembly with nongovernmental organisations, civil society organisations and the private sector,' Freedom from Want, 23 June, 2005, Introductory comments, Jean Ping, Chair http://www.un.org/ga/civilsocietyhearings/webcast.html (accessed March 15, 2010)
} 
are less likely to be experienced in public speaking and complex and theoretical discussions. The United Nations presents a particularly intimidating environment. Even seasoned NGO representatives may find it challenging to make statements off the cuff, with many depending on pre-formulated statements. I suggest that in an attempt to create an interactive debate, the request from the Chair created a barrier to participation of people living in poverty as serious as the absence of ramps to wheelchair users. In addition, these hearings were held months before the High Level inter-governmental event, which also demonstrates the marginalisation of these voices. Although the hearings showed some attempt to include NGO voices in the high-level debate, it remains symptomatic of the exclusion of people living in poverty.

This marginalisation was also evident in September 2008, during a High-Level event that brought together Heads of State in an attempt to renew commitment to the MDGs. The event, held at UN Headquarters in New York, only allowed six UN-selected 'representatives' of Civil Society ${ }^{80}$ three from the North and three from the South - to formally participate in the roundtables, and few NGO observers were allowed into the meetings. In response, a major NGO coalition, the Global Call to Action against Poverty, organised 'Poverty Hearings' outside the UN buildings. ${ }^{81}$ These hearings involved people living in poverty from several countries who were given the opportunity to testify to their experiences and make policy recommendations to a panel of experts, led by Mary Robinson, the former UN High Commissioner for Human Rights. Several pre-selected prominent persons had agreed to share these recommendations at the High-Level event. ${ }^{82}$ Although it could be suggested that participation of people living in poverty was realised in this case, their interventions were confined to a space across the road from the United Nations and they were subsequently represented by high profile people who were already active and respected within the UN system. There was an attempt at a gender and geographical balance in the representatives, and Ela Bhatt from India was able to speak on behalf of the hearings at the High Level meeting. ${ }^{83}$ However, the fact that the poor had to be represented by these eminent people in order to be heard in the UN meant that again, the voices of people living in poverty were symbolically and actually marginalised. The efforts of the UN system to include key stakeholders through the involvement of NGOs and

\footnotetext{
${ }^{80}$ United Nations Non-Governmental Liaison Service, 'Updated information on the High-level Event on the Millennium Development Goals (September 2, 2008)' http://www.un-ngls.org/article.php3?id article=520 (accessed March 15, 2010)

${ }^{81}$ GCAP 'Poverty Hearings and Women's Tribunals 2008' http://www.whiteband.org/Action/materials/gcappublications-and-booklets/gcap-poverty-hearings-and-womens-tribunals-2008 (accessed March 28, 2008) 82 GCAP 'Poverty Hearings in New York' http://www.whiteband.org/blog/archive/2008/09/23/povertyhearing-in-new-york (accessed February 20, 2010)

83 Ibid.
} 
through representation by eminent persons demonstrates that the poor are seen as effectively and legitimately represented by NGOs or others, in contrast to other identity groups.

There are repeated examples of such marginalisation that continue today, such as in the run up to the ten year review of the MDGs, which are being held in September 2010. The terms of reference for the taskforce who select participants for the Civil Society Hearings have again failed to specifically call for participation of organisations that represent the poor. Instead they are only asking that they 'represent all key geographical regions; are able to speak on behalf of a large constituency or network; and are gender sensitive and gender balanced. ${ }^{84}$ Once more the poor are substituted by and equated with anyone from the developing world and/or women.

\section{v. NGOs and their perceived representation of the poor}

The issue of representation and NGOs has been the subject of much debate and discussion at the United Nations. I argue that at the UN, people living in poverty are perceived to be legitimately represented by NGOs, resulting in a lack of targeted facilitation of the participation of this group in UN debates and processes. This results in the absence of the poor from the development of poverty eradication policy at the highest level.

As noted earlier, the right of NGOs to participate at the UN has long been a contentious issue, and NGOs are quick to respond to any potential weakening of their influence. NGOs have expressed concern that the renovations of the UN Headquarters in New York meant that the space to host NGO events was limited, and access to the main conference rooms restricted. ${ }^{85}$ Many reacted strongly to the Cardoso Report recommendation to broaden the concept of NGOs to that of Civil Society, ${ }^{86}$ suggesting that this was an attempt to dilute NGO influence and to increase involvement of the private sector, including the interests of powerful multi-national corporations that often conflict with the human rights agenda. NGOs frequently see themselves as the valid representatives of 'the people', in juxtaposition with the private sector and even with UN member states.

\footnotetext{
${ }^{84} 2010$ PGA's TASK FORCE on Hearings for the High-level Plenary Meeting of the sixty-fifth session of the General Assembly (attachment of an email to GCAP members, 'GCAP invited to be a member of Task Force of President of the General Assembly to organise CSO interactive hearings', 8 Mar 2010)

${ }^{85}$ Registration for the Commission on the Status of Women 2010 noted 'There is currently no limit on the number of representatives each organization may pre-register. However, organizations should be aware of the limited capacity of United Nations conference rooms, particularly in the context of current renovations taking place at United Nations Headquarters. Please note that in this context, entry into official meetings cannot be guaranteed.' http://www.un.org/womenwatch/daw/csw/NGO.html\#parallel (accessed February 17, 2010)

${ }^{86}$ Cardoso Report, p. 39
} 
However, NGO claims to a monopoly on representation of excluded or marginalised groups are increasingly contested as concerns grow about the dual role of development practitioners presenting themselves as both advocates for the poor as well as distributors of aid or other benefits. ${ }^{87}$ Furthermore, there is a growing recognition that the inequalities found in regular societies are also often replicated in NGOs, ${ }^{88}$ and the second hand nature of the messages given by many NGOs is problematic. I argue that these messages are often filtered and distorted in order to suit the context of the debates or meetings at the UN level, as well as to serve the strategy and message of the individual NGOs.

Membership-based organisations of the poor (MBOP) are less influential at the UN than conventional NGOs that act as both advocates and benefactors. MBOPs can be defined as 'organizations whose governance structures respond to the needs and aspiration of the poor because they are accountable to their members, ${ }^{89}$ and the poor themselves are able to have a voice, free from the power dynamic within NGOs. Such a situation is crucial for the eradication of poverty and reduction of inequality. ${ }^{90}$

A recent publication of the Non-Governmental Liaison Service (NGLS) recognises the special nature of smaller and more grassroots NGOs, calling for increased participation of such groups. Noting the imbalance of influence between the larger, professional NGOs and smaller grassroots organisations, it states that the UN 'needs the direct input of people's movements - as distinct from NGOs - in order to ensure that the policies it adopts and the programmes it implements incorporate the insights and proposals of those they are intended to support.' ${ }^{91}$ As such, it makes a clear argument that most NGOs are not interchangeable with vulnerable groups and that the facilitation of their input requires a particular consultative dynamic. Although NGOs have an important and some would say crucial place in UN processes, this recognition of the special requirements of vulnerable groups is crucial. ${ }^{92}$ In fact, other research suggests that the international policy environment can be 'downright hostile' ${ }^{93}$ to membership-based organisations of the poor, as their

\footnotetext{
${ }^{87}$ Benefits from being close to an NGO often goes beyond access to direct aid, and may include access to micro-credit funds, and status.

${ }^{88}$ Duncan Green, From Poverty to Power; How active Citizens and Effective States can Change the World (Oxford, UK: Oxfam International, 2008) p. 63

${ }^{89}$ Martha Chen et al (eds.) Membership Based Organisations of the Poor, (Oxon: Routledge, 2007) p. 3

90 Ibid. p. 3

${ }^{91}$ Nora, McKoen and Carol Kalafatic, Strengthening Dialogue: UN Experience with Small Farmer Organisation and Indigenous Peoples, (New York: NGLS United Nations, 2009), executive summary

92 Ibid.

${ }^{93}$ Chen et al, Membership Based Organisations of the Poor, (2007) p. 18
} 
views may present a challenge to the macro-level perspectives of policy makers, as well as threaten existing local power structures. ${ }^{94}$ Therefore it seems that genuine participation of the poor faces two main challenges: the existing under-representation of membership-based organisations of the poor, ${ }^{95}$ and the domination of the policy space at the UN by large NGOs.

The UN hosts many large INGOs, ${ }^{96}$ with several dominant players having a considerable effect on UN debates, both overtly and through work behind the scenes. Many make a significant financial investment in their UN work, using professional staff to build contacts and gain influence with key decision makers. I suggest that the larger NGOs enjoy a dominant and influential space in the discourse around poverty, and inadvertently, those NGOs who may be argued to be more representative of the poor, such as NGOs or MBOPs that give the poor greater voice within their organisational structure, are frequently drowned out.

Kerstin Martens, in her analysis and comparison of the impact of several large NGOs at the United Nations, concludes that NGOs are not merely influential participants in the international sphere, but have actually 'been integrated into the UN framework'. ${ }^{97}$ Those that have the capacity to have both permanent and professional representation at the UN are likely to have more influence on UN decision-makers, ${ }^{98}$ and these NGOs tend to mirror the Security Council in that they are generally from the states that won the Second World War. ${ }^{99}$ Marten finds that the limitations that apply to smaller NGOs' interactions in the UN system mean that, on their own, 'increased opportunities for activities with the UN and the correlating greater participation of NGOs does not necessarily lead to a more balanced representation of civil society in international affairs, as normative approaches often imply.' ${ }^{100}$

Furthermore, Martens' study finds that the most successful advocacy NGOs are the centralised and hierarchical ones, as they devote significantly more resources than federative NGOs to their UN activities. ${ }^{101}$ I would argue that these more successful, centralised, and large organisations are least likely to take their ongoing planning and focus for advocacy from their constituents or members, and therefore can be argued to be less representative of the poor.

\footnotetext{
${ }^{94}$ Ibid. p. 18

${ }_{95}$ McKoen and Kalafatic, Strengthening Dialogue, Executive Summary

${ }^{96}$ International Non-governmental Organisations

${ }^{97}$ Kerstin Martens, NGOs and the United Nations; Institutionalisation, Professionalisation and Adaptation (Palgrave McMillan: Hampshire, UK, 2005) p. 162

98 Ibid.

${ }^{99}$ Green, From Poverty to Power, p. 357

${ }^{100}$ Martens, NGOs and the United Nations, p. 162

101 Ibid. p. 159
} 
As NGOs have much to gain from the status and legitimacy that interactions with the United Nations confer, they also have something to lose, a concern which potentially restricts their advocacy actions. ${ }^{102}$ The fear of losing status can impact on the behaviour of $\mathrm{NGOs}^{103}$ and the threat of losing it may constrain their role as advocates for the poor. I suggest that the smaller or more grassroots NGOs, which I have argued better represent their constituents - including the poor - are less likely to have the connections and resources to mobilise support for themselves. They are, therefore, more at risk of losing their status, or being marginalised should their advocacy be unwelcome.

A further problem is the potentially distorting mix of charity and advocacy within many NGOs. Increasingly, charity-based NGOs are recognising that societal change is necessary to support grassroots efforts to help people living in poverty. Such social change necessitates greater interaction with decision making bodies at the national and international level. Thus, many NGOs now have a dual purpose - that of charitable works as well as advocating for the subjects of their charity. However, theorists have alerted us to the dangers of combining these two activities. Joseph Wresinski highlighted this problem when he declared that 'knowledge must not be the step-child of charity $^{104}$ suggesting that to combine charitable relationships with knowledge gathering impacted the results, and that the purpose of such organisations was primarily to alleviate poverty. ${ }^{105}$ Freire also notes that 'false charity constrains the fearful and subdued, the 'rejects of life', to extend their trembling hands. ${ }^{106}$ Thus, the combination of charity, which brings with it an inherent power relationship, and the facilitation of the expression of their views by people living in poverty is problematic. The ability of recipients of charity to freely express themselves to donor NGOs is questionable. Wresinski, therefore, chose to create ATD Fourth World as a 'movement (which was) without religious or political allegiance, which could in no way be defined as "charitable works."107 Today, this organisation has partnership with people living in poverty, and the facilitation of their participation in all aspects of society, avoiding charitable actions. ${ }^{108}$

\footnotetext{
102 Ibid. p. 151

103 Ibid. p. 159

104 Quentin Wodon and Xavier Godinot (eds.) Participatory Approaches to Attacking Extreme Poverty, (World Bank Working Paper 77: 2006) p. 13

${ }^{105}$ Xavier Godinot, Eradiquer la misere: Démocratie, mondialisation et droits de l'homme. (Presses Universitaires de France, Paris: 2007) English translation awaiting publication, p. 23

${ }^{106}$ Paulo Freire, Pedagogy of the Oppressed (London: Penguin, 1996) p. 27

${ }^{107}$ Godinot, Eradiquer la misere p. 18

108 International Movement ATD Fourth World 'Who are we?' http://www.atd-fourthworld.org/-Who-are-we.html (accessed April 22, 2010)
} 
Furthermore, the autonomy of NGOs who assume a dual purpose must be questioned. For many development NGOs, a significant proportion of funding comes from government contracts (especially from the states NGOs are headquartered in) to deliver programmes and projects. ${ }^{109}$ Nick Dearden highlights the problem of political co-option of UK NGOs by governmental funding managers, as up to a third of NGO income comes from national or regional government, or the national lottery. ${ }^{110}$ He notes that as UK government spending on NGO-led poverty eradication projects rose, these organisations had a greater imperative to take a cautious approach to advocacy work in order to preserve their income. In the New Zealand context, the recent example of government funding being cut to the main NGO umbrella group, the Council for International Development (CID), shortly after they spearheaded a campaign expressing concerns about changes to government allocation of ODA is a case in point. ${ }^{111}$

Moreover, the professionalization of NGO staff has meant that they effectively become the coworkers or co-professionals of the UN decision-makers, exacerbating their co-option. Dearden suggests that NGO workers and government staff and even politicians have more in common with each other than with the huge numbers of poor throughout the poorest regions in the world. ${ }^{112}$ । would argue that this is likely to be true of NGO professionals whether they be from North or South. As Dearden notes, "by bringing NGOs into the global governance system or giving them a role in corporate regulation, personal relationships are formed, power is moved from the South, enormous amounts of time are tied up; they get a stake and degree of responsibility in the system. ${ }^{113}$ This cooption then becomes entrenched, further separating NGO staff from those whom they are presumed to effectively represent. Donovan Storey highlights this trap and the difficulties of breaking out of established paradigms when he notes that

the established doctrine that serves the financial or political interests of those with money to give is re-invented in such a way that it resonates with actors across the ideological and political spectrum whilst still appearing rational and credible, thereby reducing pressure for a fundamental shift and sustaining old orthodoxies. ${ }^{114}$

In other words, the entrenchment of NGO professionals within the UN system helps to legitimise policy decisions that maintain, rather than challenge, the status quo.

\footnotetext{
${ }^{109}$ Nick Dearden "From Charity to Solidarity”, Globalizations, Vol. 3, Iss 2 (2006) p.261

${ }^{110}$ Ibid. p. 261

${ }^{111}$ Elizabeth Chan, "The Politics of Aid" NZ International Review Vol. 35 (2010) p 17

112 Dearden, "From Charity to Solidarity" p. 262

113 Ibid. p. 261

114 Donovan Storey et al, "The Poverty Consensus: Some Limitations of the Popular Agenda" Progress in Development Studies, Vol.5, Iss. 1, (2005) p. 36
} 
Nor are smaller NGOs immune to such co-option, as they tend to join committees and alliances with larger NGOs to strengthen their position and advance their goals at the UN. ${ }^{115}$ This means that they may have to make compromises in their focus in order to benefit from such alliances, potentially affecting their ability to represent their constituencies. UN efforts to increase the participation of the smaller NGOs may overlook this potential dilution of their mandate by again assuming that smaller NGOs are more representative of the views of the poor.

The recognised influence NGOs have in international decision making means that querying the legitimacy of their representation is extremely important. Warren Nyamugasira states very clearly that 'all NGOs tend to be self-appointed, and neither consult nor give feedback to their constituencies. $^{1116}$ Rejecting the harshness and universal application of this statement, I suggest that some NGOs do maintain genuine consultation and accountability. These more inclusive NGOs have chosen to consistently refer back to their core mission of participation of the poor, and to avoid mixing charity with advocacy. ${ }^{117}$ Unfortunately, such NGOs are often as invisible to researchers and academics as they are to the decision makers. Furthermore, such organisations often encounter strong resistance to their efforts to ensure people living in poverty can participate in the UN; highlighting the difficulties of the UN system.

There are examples, however, of UN efforts to ensure that NGOs are more transparent and engage the poor in a more genuine way. The 2008 request for input into the United Nations Draft Guiding Principles on Extreme Poverty and Human Rights noted the importance of addressing this issue of the freedom of expression that people living in poverty have within NGOs. The Human Rights Council invited various stakeholders to comment on the draft guidelines, including 'nongovernmental organizations, especially those in which people in situations of extreme poverty express their views. ${ }^{118}$ This is a clear acknowledgement by the UN of the limitations of substituting NGOs for the poor and the need to clearly separate request for input from NGOs from a request for input from the poor themselves.

\footnotetext{
${ }^{115}$ Martens, NGOs and the United Nations p. 159

${ }^{116}$ Warren Nyamugasira, "NGOs and Advocacy: how well are the poor represented?", Development in Practice, Vol. 8, Iss.3, (1998) p. 300

${ }^{117}$ Such as ATD Fourth World, the Huairou Commission and other Membership Based Organisations of the Poor

${ }^{118}$ The Office of the High Commissioner of Human Rights, The Draft Guiding Principles on Extreme Poverty and Human Rights: the rights of the poor http://www2.ohchr.org/english/issues/poverty/consultation/index.htm (accessed April 19, 2010) para. 4
} 
I argue that the perception that NGOs always validly represent the poor must be questioned more thoroughly and the problems highlighted in the spheres where they have most influence. Dearden suggests that many NGOs actively manage the voices of the poor and:

fundamentally misunderstand the process of social change. They think it is about educating people in power. Partly this is a response to the relatively apathetic society we live in. But it also reflects the internal dynamics of most NGOs - they want to keep firm control. If they can say they represent 1 million people, that gives them weight and importance; if those 1 million people really start speaking it removes that importance - and heaven knows what they will say. ${ }^{119}$

Although there are an increasing number of NGOs who recognise this problem, as well as an increasing number of NGOs that recognise that extreme poverty is a human rights issue, few state categorically that direct participation of the poor at the United Nations level is important, and even fewer prioritise the facilitation of such participation.

I argue that the status quo, in which NGO voices at the UN are dominated by those organisations that mix charity and advocacy; have centralised and hierarchical structures; have professional staff who have more in common with the elites of the UN system than the poor; and have funding streams that potentially compromise their autonomy, is problematic. In this status quo, the United Nations perceive the poor to be legitimately represented by NGOs or Civil Society, and continues to believe that the participation of people living in poverty is realised effectively at the local level through NGOs. Further action to increase their participation at the UN is, therefore, seen as unnecessary. This serves to exclude the poor from having a meaningful presence at the highest level of policy making.

${ }^{119}$ Dearden, "From Charity to Solidarity" p. 262 


\section{vi. The United Nations idea of participation of the poor sits primarily at the local}

The United Nations has recognised the importance of participation of people living in poverty. However, I argue that such participation is generally accepted as belonging to the national or local sphere. The state-led Poverty Reduction Strategy Papers of the early 2000s - developed after the increasing requests for policy space by developing countries after the imposed conditionalities of the Western-led structural adjustment policies of the 1980s - exemplify and reinforce this dynamic. The PRSPs represented the assertion by developing countries of domestic sovereignty over the formulation of poverty reduction strategies, and a strengthening of domestic participation. A side effect of this move, however, is that the UN, in combination with development NGOs who have stepped into an advocacy role, ${ }^{120}$ has devolved the participation of the poor primarily to the domestic or local level. This is affirmed in a 2004 General Assembly resolution which stated that (the member states of the United Nations)

... reaffirm that it is essential for States to foster participation by the poorest people in the decision-making process in the societies in which they live, in the promotion of human rights and in efforts to combat extreme poverty, and that it is essential for people living in poverty and vulnerable groups to be empowered to organize themselves and to participate in all aspects of political, economic and social life, in particular the planning and implementation of policies that affect them, thus enabling them to become genuine partners in development. 121

However, texts such as these, in which calls for participation are targeted - or are interpreted as targeting - primarily the domestic level, mean that the poor are rarely present at the United Nations.

Meanwhile, the importance of their participation is repeatedly emphasised at the UN. In 2006, the Report of the UN Secretary General on the Observance of the International Day for the Eradication of Poverty stated that 'poor people perceive poverty differently and such dialogues can promote a shared understanding of poverty among implementers and recipients of poverty assistance. $^{122}$ The Under Secretary General of Economic and Social Affairs noted in 2008 that:

\footnotetext{
120 Ibid.

121 United Nations General Assembly Resolution “Human Rights and Extreme Poverty" A/RES/59/186, para. 2 emphasis mine

122 United Nations Report of the Secretary General on observance of the International Day for the Eradication of Poverty A/61/308, (2006) para. 56 (d) p. 18
} 
(p)overty is more than inadequate income or human development. Poverty is also about lack of voice, power, and representation. One effective way to address these various dimensions of poverty is through the empowerment and participation of poor people in decision-making that affects their lives. ${ }^{123}$

Similarly, the recent Draft Guiding Principles on Extreme Poverty and Human Rights devoted an entire section to participation, stating that

(p)ersons living in extreme poverty have the right to participate in all activities which concern them, particularly programmes for the eradication of extreme poverty. The implementation of such policies and programmes without the participation of the persons concerned and their associations and organizations constitutes a violation of the right to participate in public affairs. ${ }^{124}$

Research has shown that more attention should be paid to the empowerment, participation and engagement of the poor as essential pre-requisites for pro-poor growth, which supports the assertions made in UN documents calling for greater participation and empowerment of the poor. ${ }^{125}$ However, the Overseas Development Institute, a leading think tank on development issues, notes that participation remains an ill-defined concept: 'In some cases this means participation by marginalised groups in economic policy-making, in others the focus is on participation in the labour market and productivity. ${ }^{126}$

Furthermore, the Independent Expert on Human Rights and Extreme Poverty stated clearly in 2008 that:

it is crucial that people living in poverty participate in the design, implementation and monitoring of public policies that affect them. These are essential human rights that States must provide and protect. Citizens have a right to participate in public life and States must ensure that people's voices are expressed and heard when public policies are put in place. By

\footnotetext{
${ }^{123}$ Sha Zukang, Foreword to 'Turning Rhetoric into Action: Building effective partnerships to combat extreme poverty and exclusion,' by International Movement ATD Fourth World (New York: 2008)

${ }^{124}$ Resolution 2006/9. Implementation of existing human rights norms and standards in the context of the fight against extreme poverty

${ }^{125}$ Marta Foresti et al, Overseas Development Institute Project Briefing 34, (January 2010) p. 2

${ }^{126}$ Ibid.
} 
participation, we do not mean mere consultation: States must make sure the participation of people living in poverty is meaningful and has an impact on decisions and social policy. ${ }^{127}$

This recognition of the need for participation of people living in poverty (as opposed to the topdown driven initiatives that used to dominate development practice) is the result of a concerted effort by NGOs over many years. However, it has been broadly interpreted as being effectively realised at the local level. Although local participation is important in order to ensure that certain groups are reached, it is unrealistic to think that the concept and integrity of participation can remain meaningful and valid when realised only at one level.

While the UN, through its understanding of participation, has been instrumental in localising participation by people living in poverty, I argue that NGOs are as complicit in perpetuating this localisation the UN itself. Since the establishment of the UN, NGOs have worked hard to create and retain their presence in its corridors, chambers and conference rooms. An enormous amount of effort and strategising must occur to make positive changes to policy and the NGOs who are most effective in this space are highly professionalized, ${ }^{128}$ implementing well-planned interventions and mounting large-scale lobbying activities. Their key messaging and strategies are the result of much preparation and professional input. To step aside and allow people living in poverty to have a genuine voice risks affecting that work.

Large NGOs ${ }^{129}$ have contributed much literature to the debate around participation of people living in poverty, though with observations and recommendations that again and again return to the local. For instance, in 2009 Duncan Green made a compelling argument for participation of people living in poverty when he stated that they 'must have a voice in deciding their own destiny, rather than be treated as passive recipients of welfare or government action. ${ }^{130} \mathrm{He}$ went on to argue that in order for efforts to be successful, people must be treated as subjects, 'conscious of and actively demanding their rights'. ${ }^{131}$ However, in making a hopeful plea for a fair global governance in the twenty-first century, he tended to emphasise the local, saying

with all its limitations, global governance holds out the promise of building some fairness and predictability into international relations by reining in the powerful, ensuring that

\footnotetext{
127 UN-NGLS 'Interview with Magdelena Sepulveda Carmona, Independent Expert on Human Rights and Extreme Poverty, October 21, 2008.' http://www.un-ngls.org/spip.php?page=article s\&id article=597, (accessed February 19, 2010)

${ }_{128}$ Martens, NGOs and the United Nations

${ }^{129}$ Although writers such as Michael Edwards and Duncan Green note that their views do not necessarily reflect the views of Oxfam, they both have connections with the organisation

${ }^{130}$ Green, From Poverty to Power p. 12

131 Ibid. p. 13
} 
poor nations have sufficient policy space and resources to work their way out of poverty and helping the most vulnerable. ${ }^{132}$

Furthermore, in his illustration of the civil society led campaign that resulted in the 1997 Land Mine Treaty, he mentioned the core involvement of NGOs who were engaged in providing prosthetics, mine clearing, and documenting human impacts. ${ }^{133}$ This focus on the efforts of the NGOs rather than the victims counters his earlier plea to consider people as actors, rather than passive recipients. I suggest that recognising and facilitating the participation of people living in poverty requires constant vigilance, even for the most well-intentioned and reflective NGOs.

NGOs have argued for many years of the importance of participation. In 1989, Michael Edwards lamented the lack of action on genuine participation of the poor which, he suggested, makes development irrelevant. He noted that the technical approach of development serves to devalue indigenous knowledge, leading to an inevitable failure to find workable solutions to what are often localised problems. ${ }^{134}$ As research on development moved towards a more inductive approach, 'the local' became 'the site of empowerment and hence as a locus of knowledge generation and development intervention. ${ }^{135}$ In making a convincing case for the need for people living in poverty to participate in poverty eradication initiatives, the focus has necessarily been initially local, with NGOs content to continue to represent the poor at the international level. However, this focus has remained, and NGO representation occurs even though NGOs often stress the importance of participation at the UN. More often than not, the phrase participation means, in the context of the UN, that of NGOs, not the poor themselves. For example, the umbrella organisation $\mathrm{CONGO}^{136}$ has a stated aim of facilitating the participation of NGOs at the UN, however, it does so with little reference to the make-up of NGO memberships other than the requirement to hold UN consultative status. $^{137}$

In summary, this section has introduced an emerging literature that suggests that participation by the poor in decision making is primarily situated at the local level. I argue that the UN and the NGOs working within the UN system tend to reinforce and reproduce such localisation of participation through their failure to consider people living in poverty as forming an interest group that can represent itself, and the concomitant acceptance of NGOs as legitimate representatives of

\footnotetext{
${ }^{132}$ Ibid. p. 424

${ }^{133}$ Ibid. p. 403

${ }^{135}$ Giles Mohan and Kristian Stokke, "Participatory Development and Empowerment: The Dangers of Localism," Third World Quarterly, Vol. 21, No. 2 (2000) p. 247

${ }^{136}$ Conference of Non-Governmental Organisations in Consultative Relationship with the United Nations

${ }^{137}$ CONGO, 'About CONGO' http://www.ngocongo.org/about (accessed March 18, 2010)
} 
the poor. I further argue that the participation of people living in poverty at the United Nations level is crucial to the efforts to eradicate poverty. I suggest that the NGOs and UN relinquish their power, curb their tendency to represent, and push to facilitate genuine participation of the poor at the UN. Although I am not recommending that such participation should replace local efforts, there are clear limitations associated with the retention of local participation alone, as this tends to maintain the abstraction of poverty, and serves to further marginalise the poor, thus preventing the poor from being able to lead their own liberation from poverty. 


\section{Why is it important that people living in poverty participate at the UN level?}

In this section I argue that participation at the UN by people living in poverty should be recognised as an important precondition for real change to occur. Local participation of this group, as preferred by the UN, has serious limitations, which I argue, serves to reproduce and exacerbate the power imbalances that disadvantage the poor. The dominance of statistical and expert language at the UN prevents participation by the poor, while abstracting the realities of their lives, rendering horrifyingly significant decisions morally and politically possible. Furthermore, the focus on statistics leads to a reduction of potential solutions and instead promotes mainly quantitative, economic-based options, which potentially further marginalise the poorest. The participation of the poor has the potential to challenge the entrenched preconceptions of decision makers, demonstrate the harsh reality of the world's ongoing poverty and result in urgent action, allowing the poor to reclaim their dignity.

\section{i. Local participation alone has limitations}

The predominant assumption made by the UN that the poor's participation is effective and legitimately positioned at the local level alone has serious implications. Emerging literature sets off warning lights - participation of the poor is frequently managed by NGOs based in the North, and even locally-run participation often perpetuates local power imbalances. An uncritical acceptance of the effectiveness of local participation brings with it several risks, including the further marginalisation of the less influential members within poor societies, while local elites are more able to take advantage of the new avenues of influence because of embedded power structures. For instance, commonly used consensus-based approaches 'may actually empower the powerful vested interests that manipulated the research in the first place ${ }^{138}$ and result in further marginalisation of the poorest members of a given society. In addition, the aforementioned problem of mixing charity with participation inevitably results in a problematic power relationship. These failings, combined with an overreliance in the UN system on poverty researchers who position themselves as experts are detrimental to participation at the international policy level. This is potentially damaging to the efforts to eradicate poverty, and I therefore suggest effective participation must occur at both levels.

${ }^{138}$ Mohan and Stokke, "Participatory Development and Empowerment" p. 253 
Brand notes that the very poorest are often the least seen and most overlooked. ${ }^{139}$ Their extreme poverty and vulnerability ensure that their voices are drowned out by those who are still secure enough to be able to speak up for their rights, but are gripped by the fear of entering extreme poverty. It is often the case that those who speak the loudest have not yet been marginalised and humiliated into silence by their poverty. This dynamic is often lost on Northern constituencies because the striking inequality between the North and South means that many in the North see the majority of those in the South as poor (which of course they are, but they are not the poorest) and therefore believe that the poor have spoken. Those who are the poorest and most vulnerable within a society are thereby further marginalised, their participation overlooked, their silence ensured by their shame, 'never daring to accuse the world of indifference to human rights.' 140

A further concern is that by focusing on the local, the present power dynamics and social inequalities are overlooked or downplayed, leading to the 'tendency to view the local in isolation from broader economic and political structures. ${ }^{141}$ As noted earlier, the UN has asserted itself in a central role for the development of policy aimed at eradicating poverty. However, by analysing poverty in local pockets, the UN risks paying inadequate attention to the global structural inequities that underlie much current inequality. As noted in the previous section, which questioned the validity of knowledge generation that is combined with charity, Stokke and Mohan's concerns about the 'political nature of participation'142 and the power imbalances associated with participation support reasonable suspicion of the efficacy of local processes in ensuring the voices of the poor are heard. I concur with their argument that it is problematic to over-value participation and empowerment at the local level. ${ }^{143}$

Further research voicing concerns about the situating of participation at the local level include Frances and James' examination of the contradictions of Uganda's poverty reduction programme. They express concern that efficiency and empowerment may in fact be working against each other at the local level. In this case, the supposedly participation-enhancing structure failed to create an environment which constitutes 'a genuinely participatory system of local governance. ${ }^{144}$ Also

\footnotetext{
139 Eugen Brand, 'Hunger for Bread, Hunger for Roses' http://www.atd-fourthworld.org/Hunger-for-BreadHunger-for-Roses.html?var recherche=bread\%20for\%20roses (accessed April 18, 2010)

140 Ibid.

${ }^{141}$ Mohan and Stokke "Participatory Development and Empowerment" p. 249

142 Ibid. p.252

143 Ibid. p. 252

${ }^{144}$ Paul Francis and Robert James, "Balancing Rural Poverty reduction and Citizen Participation: The Contradictions of Uganda's Decentralization Program” World Development, Vol. 31, No. 2 (2003) p. 334
} 
focusing on Uganda, Craig and Porter note that the PRSP phenomenon masks power imbalances, and they highlight limitations imposed by the process:

'the tunnel vision inherent in inclusive liberal frameworks applied at a distance... has limited scope and options available to local actors. In a wider context, insofar as the "electronic herd" and ratings agencies have reified simplistic and sharply conservative settings, this problem has been exacerbated.' ${ }^{145}$

They find that PRSPs do not empower, but rather may inhibit participation. Furthermore, I suggest that the impact of the poor is diluted through their participation in the PRSPs, and must therefore be negligible when compared with the impacts of how people living in poverty and poverty itself are otherwise presented within the international discourse. ${ }^{146}$

At the local level, NGOs are the natural facilitators of participation by people living in poverty. Many NGOs see themselves as being very close to, or as organisations of the poor. However, as mentioned in a previous section, NGOs have their own problems when it comes to facilitating the participation of the poor at the local level. A significant danger of local NGO-led participation lies in the temptation of NGOs to distance themselves from those they purport to represent as their status increases. ${ }^{147}$ Nyamugasira suggests that even Southern NGOs lack closeness to the poor and that they use the status and wealth associated with international funding to move closer to the elites of their own country or to their Northern NGO colleagues. He states bluntly that they 'can be accused of patronizing the poor. They love status and are committed to maintaining the status quo so long as it works in their favour. They have... problems of vision and accountability in relation to their locallevel partners. ${ }^{148}$ He takes this criticism further still when he says that 'even in loco, Southern NGOs can, at times, be a poor imitation of and often distort the voice of this silent mass. ${ }^{149}$

Beyond participation, I suggest that an over-reliance on the opinions of 'experts' who study the nature of poverty rather than upon the poor themselves is problematic because it creates and cements the perception of the poor as people who must be spoken for rather than producers of their own knowledge. Wresinski questioned the validity of poverty researchers, who are extremely influential within the debates and policy formulation at the UN. He suggests that as the poor are

\footnotetext{
145 David Craig, and Doug Porter, "Poverty Reduction Strategy Papers; A New Convergence," World Development, Vol. 31, No. 1 (2003) p. 67

${ }^{146}$ Bracking and Hickey, "Exploring the Politics of Chronic Poverty" p. 854

${ }^{147}$ Nyamugasira, "NGOs and advocacy" p. 301.

148 Ibid.

${ }^{149}$ Ibid, p. 300
} 
turned into subjects of research, they are exploited rather than treated as partners and experts. Similarly, Godinot critiqued traditional research methods by suggesting that although ethical considerations of the need for a participatory approach to poverty eradication have improved, many supposedly participatory initiatives fail to involve people with experience of poverty at all stages. Instead, they are most often included with the intention of extracting information from them, rather than partnership or participation. ${ }^{150} \mathrm{He}$ describes this process as 'extractive'.

By failing to recognise the potential of this partnership, researchers 'upset or even paralyse the thinking of their interlocutors. ${ }^{151}$ Furthermore, as researchers fail to see the poor as agents of praxis who have the ability to reflect and act on their own situations, their research findings are questionable. Wresinski also questions the validity of the participatory observation of the anthropological field, noting that this process 'runs the danger of misusing, tampering with, and paralyzing the thinking of the poor. ${ }^{152}$ As the goal of the interaction is 'external to their life situation, ${ }^{153}$ the results can never have the same validity as conclusions that come from the poor themselves. Freire echoes this, noting the difficulty of including the oppressed (or poor) as partners in the quest for knowledge about the nature of poverty: 'So often do they hear that they are good for nothing, know nothing, and are incapable of learning anything ... that in the end they become convinced of their own unfitness.' ${ }^{154}$ Their learned response is to defer to the 'expert'.

Freire and Wresinski agree that research may have negative impacts on the lives of the poor and the oppressed. Wresinski says that 'to hinder the poorest by using them as informants rather than encouraging them to develop their own thinking as a genuinely autonomous act is to enslave them. ${ }^{155}$ Similarly, Freire notes that a 'pedagogy which begins with the egoistic interests of the oppressors (an egoism cloaked in the false generosity of paternalism) and makes of the oppressed the subject of its humanitarianism, itself maintains and embodies oppression. It is an instrument of dehumanisation. " ${ }^{156}$ Furthermore, it is the policy maker, researcher or teacher who records the words of the poor, choosing which testimony or input is retained and transmitted to others and which is disregarded and goes unheard. ${ }^{157}$ All of the academic studies in the world, unless they

\footnotetext{
${ }^{150}$ Wodon and Godinot (eds.) Participatory approaches to Attacking Extreme Poverty, p. 33

151 Joseph Wresinski 'A Knowledge that leads to Action' in Quentin Wodon and Xavier Godinot (eds.) Participatory Approaches to Attacking Extreme Poverty, (World Bank Working Paper 77: 2006) p. 15

152 Ibid. p. 16

153 Ibid.

154 Freire, Pedagogy of the Oppressed, (London, Penguin: 1996) p. 45

155 Wodon and Godinot (eds.) Participatory approaches to Attacking Extreme Poverty, p. 18

${ }^{156}$ Freire, Pedagogy of the Oppressed, p. 36

${ }^{157}$ Dorothy Lander, "Writing as witness: Doing justice to participants' testimony" Adult Learning, Vol. 12, Iss. 3 (Summer 2001) p. 17
} 
included genuine input from the poor, would not include important sections of knowledge. ${ }^{158}$ Rather, they, and the use of these studies at the international level, represent a reification of what it means to be poor.

In summary, many NGOs seem content to limit participation by people living in poverty to the local level and represent the extracted 'findings' at the international level themselves. The strong presence of Northern NGOs in developing countries mean that such NGOs are often the facilitators of such participation because they act as a conduit between the developing country governments and the local beneficiaries of poverty eradication programmes. But the education and power imbalances, frequent lack of local knowledge, hierarchy, bureaucracy and a sense of gratitude from and the fragile status of beneficiaries all combine to problematise NGOs' representation of the poor at the international level. Furthermore, when influential Northern NGOs assume (perhaps wrongly) that because an NGO is from the South it must have a membership or mandate of the poor, they further sideline people living in poverty. The UN has, by placing participation of the poor at the problematic local level, co-opted and taken away ownership of the issue of poverty from the poor themselves.

\section{ii. The abstraction of poverty and the importance of language}

The United Nations has a significant ownership of the debate around poverty, partly through their framing of the debate within an exclusionary epistemology. They have developed and reproduced this through the use of a particular kind of statistic-dominated 'expert's' language, which excludes the poor from participating in this dialogue. Not only does the predominant use of statistics and economic indicators serve to abstract and dehumanise the poor, the use of a specialist language excludes the poor from meaningful participation in the development discourse.

In the absence of the poor, decision makers participating in the UN debates are free to speak about the poor, count them, and co-opt aspects of their existence to justify various policies. Within this debate, the UN discourse on poverty is framed by the use of statistics, goals, targets, and numbers and thereby limited to considerations for which such quantitative tools and measures are meaningful. I argue that the use of statistics has become the legitimate framework for the debate on poverty and is the central feature for measuring progress. For example, the dominant style of the discourse on poverty at the UN is to count the number of people living in poverty one year, check

\footnotetext{
${ }^{158}$ Wodon and Godinot (eds.) Participatory approaches to Attacking Extreme Poverty p. 16
} 
again in the next, and then proclaim whether efforts have been a success or not. ${ }^{159}$ This abstraction of the issue serves to separate the decision makers from the realities of the lives of people living in poverty, and enables them to make decisions and to act or fail to act with more ease than if they were confronted with situation face-to-face. When the presence of people living in poverty in the UN inserts emotion into the debate, the reaction is often dismissive largely because the statistical paradigm is far more familiar to the elites. I suggest that it is possible to characterize the overt use of statistics as a form of biopower and therefore another mechanism for the exclusion of the poor from the UN.

The dangers of a focus on goals, targets and statistics are evident when one examines the history of the MDGs. At the 1996 Rome World Food Summit, in a precursor to the goals, 186 governments agreed to reduce 'the number of undernourished people to half their present level by $2015{ }^{160}$ With a simple change of language in the Millennium Declaration to a commitment to instead halve the 'proportion' of people living in extreme poverty, the actual number of people who are planned to be free of poverty by 2015 was reduced by 101.5 million. ${ }^{161}$

While the MDGs continue to be hailed as an important road map to improve the lives of millions of people, Tomas Pogge notes that if they are to be achieved by 2015 - which looks unlikely - the international community has still agreed that 'only' 14 million people are to die from poverty each year, and that during the period of the MDGs, the death toll from poverty related causes should 'only' be 240 million people. Pogge rightly asks whether this is a plan that is acceptable from a moral point of view, let alone celebrated. ${ }^{162}$ I suggest that the acceptance of such an inhumane outcome by the international community is made possible through the abstraction of harsh reality through the use of statistics, and the discussion of people living in poverty as numbers rather than real people. The decision makers are able to abstract the issue - to keep emotion and messy reality out.

Pogge has also taken issue with the World Bank's statistical measures of the poor. Writing with Sanjay Reddy, he notes that the commonly used $\$ 1$ a day poverty line 'cannot correspond to what poverty means since it means nothing in particular. ${ }^{163}$ The authors highlight the problem with

\footnotetext{
${ }^{159}$ United Nations 'MDG Monitor' http://www.mdgmonitor.org/ (accessed February 20, 2010)

160 Pogge, "The First United Nations Millennium Development Goal” p. 378

${ }^{161}$ Ibid. p. 378

162 Ibid. p. 386

163 Sanjay Reddy and Thomas Pogge, "How not to count the poor! A reply to Ravallion",( August 15, 2002) http://www.columbia.edu/ sr793/poggereddyreply.pdf (accessed January 4, 2010) p. 3
} 
statistics by referring to a proposal to periodically update the purchasing power parity features of the international poverty line. This means that changes in the world economy would lead to adjustments in national poverty lines, even if the living standards of the poor in those countries have not changed. ${ }^{164}$ Therefore, in spite of little to no change in the realities of the lives of people living in poverty, the statistics may show that they are less poor. The use of statistics therefore, has the potential to breed inaction by hiding the realities.

A further critique of the reliance on statistics lies in the ability to manipulate successes to suit political goals. Due to the UN interpretation of the baseline year as 1990 rather than the MDG adoption year of 2000, the dramatic success of China in reducing its number of poor by 150 million is able to be counted as progress towards the goal. ${ }^{165}$ As Pogge points out, this means that East Asia and the Pacific achieved its goal before the goal was even adopted. Statistics can therefore be used to perpetuate the public view that global poverty is in decline, potentially resulting in complacency. Frequent politically-driven contradictory announcements about progress or otherwise towards the MDGs may lead to a public perception that the MDGs have made a substantive difference, resulting in reduced urgency of global action.

Already, we can compare the political will and action between types of 'tragedies'. We are encouraged to celebrate when UNICEF announces that 8.8 million children die annually before their fifth birthday ${ }^{166}$ instead of the previous 12.5 million per year in 1990. The survival of an additional 3.7 million children per year is certainly something to be recognised and applauded. However, if we compare such numbers of deaths to previous atrocities, such as the Rwandan genocide and the Holocaust, ${ }^{167}$ the difference in the level of outrage with which the issue is received is striking. Where is the decisive international action to prevent such loss of life from happening again? It is in actuality, allowed to persist.

Central to such arguments is that the existence of extreme poverty is an emergency and must be treated as such. Rather than poverty being treated as an emergency in the sense of provoking immediate and effective political action, I suggest that it is managed with a form of biopower. According to Michael Dillon, 'we do not widely understand the kinds of imperatives to which the biopower of biopolitics now orders the political rationalities and governmental technologies of the

\footnotetext{
164 Ibid. p. 3

165 Ibid. p. 5

166 UNICEF Media Centre “Global Child Mortality Continues to Drop" September 2009, http://www.unicef.org/media/media 51087.html (accessed April 19. 2010)

${ }^{167}$ Pogge, "The First United Nations Millennium Development Goal” p. 386
} 
west. ${ }^{168}$ Essentially, it controls and reduces its subjects to bare life, as subjects rather than humans. By excluding the voices of the people who are experiencing it, it hides the traumatic real, ${ }^{169}$ allowing the political processes to continue with the social order fundamentally unchallenged.

I suggest that this use of biopower has the consequence of objectifying and dehumanising people living in poverty, adding to the dehumanizing effect of poverty itself. ${ }^{170}$ Jenny Edkins uses the examples of recent terrorist attacks in industrialised countries to demonstrate the objectification and dehumanization of the victims through the management process, noting that they were reduced to objects and stripped of their 'personhood'. The status and management of such events as emergencies meant that the victims were reduced to 'bare life. ${ }^{171}$ Edkins notes that

In parallel with the global spread of states of exception ... we can track a global spread of forms of social interaction, governance and communication that produce life as bare life. Examples are numerous and widely discussed: the humanitarian interventions of the 1990s and the famine relief efforts of the 1980s, where life was something that was to be 'saved', nothing more victims were not given a political voice - and the terrorist attacks and arbitrary detentions of the present decade, where once more life is disqualified... ${ }^{172}$

I argue that we may apply this 'instrumentalisation or commodification of life ${ }^{173}$ to how the poor are regarded as subjects or victims by the UN on an ongoing basis. The dearth of efforts to facilitate the meaningful participation of people living in poverty in global governance is a symptom of the dehumanisation of the poor. This subjectification of the poor and abstraction of the realities of poverty serves the member states of the UN well, as they are more easily managed as victims of a global emergency than as stakeholders. I argue that we may legitimately look at the UN's use of statistics to manage the 'emergency' that is global poverty, and conclude that people living in poverty are (further) dehumanised in this process through the use of biopower.

\footnotetext{
${ }^{168}$ Michael Dillon, “Governing Terror: The State of Emergency of Biopolitical Emergence” International Political Sociology 1, (2007) p. 8

169 Jenny Edkins, Trauma and the Memory of Politics, (Cambridge: Cambridge University Press, 2003) p. 12

170 Joseph Wresinski, "The Very Poor, Living Proof of the Indivisibility of Human Rights" p. 12

171 Jenny Edkins, "Biopolitics, communication and global governance", Review of International Studies 34 (2008), p. 231

${ }^{172}$ Ibid. p. 212

${ }^{173}$ Ibid. p. 211
} 
This abstraction also serves to soothe the conscience and reduce the perception of ongoing responsibility for the citizenry of the North. While few place responsibility for the existence of poverty solely on the citizens of richer countries, poverty is a result of historical actions that the citizens of the north continue to benefit from. Pogge points out that

our great privileges and advantage as well as their extreme poverty and disadvantage have emerged through an historical process that was pervaded by unimaginable crimes... second... we are implicated because we are using our economic, technological, and military advantages to impose a global institutional order that is manifestly and grievously unjust. $^{174}$

The use of statistics to manage poverty enables those who continue to benefit from the current situation to avoid confronting the consequences of their own inaction. Regarding the poor as an abstract grouping - rather than as people, children, and families who have more commonalities with 'us' than differences - enables us to avoid confronting our continued role in the maintenance of poverty in the world and to avoid having to take urgent, substantive action.

This abstraction is reinforced through the use of exclusionary language. The importance of language in constructing the parameters and epistemological framework of the debate must not be underestimated. The type of language used during the poverty discourse at the UN impacts on whether the poorest members of society are taken into account; ${ }^{175}$ it has the power to include or exclude; it frames the debate and restricts the range of solutions; and in the poor's absence, the way poverty and the poor are represented form and shape policy and practice for poverty eradication. ${ }^{176}$ Moreover, 'discourse is also practice; it is not simply a way of understanding or thinking about the world, it is also a way of acting in it. ${ }^{177}$ As such, language has a huge part to play in creating and reproducing discourse as well as social reality.

This ownership and exclusivity of the language through which knowledge is examined leads to the devaluation of some forms of knowledge and the legitimatisation of others. As noted in an earlier section, traditional research methods of acquiring knowledge about poverty are still

\footnotetext{
174 Pogge, "The First United Nations Millennium Development Goal” p. 390

${ }^{175}$ Bracking and Hickey, "Exploring the Politics of Chronic Poverty" p. 855

176 Ibid.

${ }^{177}$ Christine Walley, "Searching for 'Voices': Feminism, Anthropology, and the Global Debate over Female Genital Operations," Cultural Anthropology, Vol. 12, No. 3 (1997), p. 430
} 
dominant, with researchers conducting studies and asking questions of the poor. Researchers tend to have a Eurocentric perspective and bring with them assumptions and constructs that lace limitations on the scope of responses to their questions. As Edwards states: '(t)he natural concern for technical interpretations of reality is that knowledge, and the power to control it, becomes concentrated in the hands of those with the technical skills necessary to understand the language and the methods being used. ${ }^{\prime 17}$ This not only transfers the ownership of such knowledge from the powerless to those who have the power as a result of their education and training, but it also excludes the poor. As Edwards points out, this reality justifies the thousands of expatriate 'experts' in the world today. In addition, I suggest, it also helps the NGOs to establish their participation in the high level debates, as they are among the few seen as legitimately able to transfer the knowledge from the local to the UN sphere.

I have personally experienced the difficulties of breaking through the barriers presented by the use of a specialised language at the United Nations in New York. On joining NGO committees, most new members struggle through their first meeting, as members speak of the upcoming ' $\mathrm{CSocD}^{\prime}$, the committee for 'FFD', how to participate in the 'DCF', what 'GCAP' is planning and what the 'UNSG' said. There is a particular language of the United Nations and the community has developed many shortcuts in their language. Until you learn to adjust, the use of this language can be intimidating and exclusionary. The initial shock of having to learn to express your views in a new UN 'language' can knock the confidence of even a highly educated professional. For people living in poverty, who usually have a short visit to the United Nations, this can be almost impossible to overcome in a short space of time.

This, in essence, takes the discourse away from those who have experienced the issue being discussed, and places it in someone else's care. For example, Christine Walley's study on Female Genital Operation (FGO) ${ }^{179}$ suggests that so called 'expert' knowledge of FGO is situated with the elites who advocate on behalf of the 'victims.' Being outside of the actual experience, experts are free to discuss it, but have little intimate knowledge of the experiences of those who go through it. 180 I suggest that inferences of this argument may also be applied to the issue of poverty in that NGOs and other experts have developed a language around the issue that serves to exclude the people who have actual experience of it and this pattern is self-reinforcing.

\footnotetext{
${ }^{178}$ Michael Edwards, "The Irrelevance of Development Studies" Third World Quarterly, Vol 11, No. 1 (1989) p. 118

${ }^{179}$ Christine Walley, "Searching for "Voices": Feminism, Anthropology, and the Global Debate over Female Genital Operations," Cultural Anthropology, Vol. 12, No. 3 (Aug., 1997), Recognising the importance of naming an issue, Walley uses the term Female Genital Operations.

${ }^{180}$ Ibid. P. 419
} 
A further unintended effect of this use of a particular abstract and organisation specific language is that it limits the debate to certain participants and outcomes. The dominance of the neoliberal economic paradigm excludes the poor from being able to participate in what have become sophisticated economic debates. Furthermore, it leads to a reduced number of policy responses that are seen as applicable in order to combat poverty - these are predominantly economic. One effect of this has been an emphasis on the category of poor who have the potential to become economic actors. The popularity of micro-credit initiatives ${ }^{181}$ and co-operatives are an example of this, as they are focused on the integration of productive actors into the economic mainstream. There is little consideration as to whether the chronically poor - who are also experiencing social exclusion and often the contempt of their community - can benefit from such initiatives, and the oft-heralded success in reducing poverty of certain groups, in particular women, obscure the fact that the inequalities between the success stories and the 'Fourth World' is increased. The focus on the MDGs also reproduces this dynamic - with the target of $50 \%$ reduction of poverty by 2015 , any statistical success counts, and the realities of the poorest are irrelevant to the success or failure of this flagship political agreement as long as benchmarks are met.

This thesis argues that although the poor should be able to speak for themselves, the technical nature of the debate about poverty means they are again excluded and condemned to be outsiders in their own issue. The importance of their inclusion is reinforced by Edkins' assertion that 'communication takes place in language and language itself is social and political, not individual.'182 When people living in poverty are excluded from participating through language, they are also excluded from the construction of social and political realities. This exclusion gives considerable power to NGOs and experts as they gather information and 'translate' the experiences of their subjects to the UN processes.

I suggest that certain issues that are taken up by identity groups in the North on behalf of their Southern counterparts underline the political nature of representation. Walley's study finds that representatives often use the issues to suit their political goals. ${ }^{183}$ This means the perception held by the decision makers are affected by the focus imposed by participants in the international discourse, rather than those who experience the issue being discussed. She also notes that the discourse around FGO 'invokes a series of binary oppositions, including, first world, third world,

\footnotetext{
${ }^{181}$ Bracking and Hickey, "Exploring the Politics of Chronic Poverty" p. 855

${ }^{182}$ Edkins, Trauma and the Memory of Politics, p. 7

${ }^{183}$ Walley, "Searching for "Voices, p. 408
} 
modernity, tradition, ... freedom, torture repression..., medical knowledge, ignorance/disease ${ }^{184}$ and that the cumulative effects of these binary oppositions perpetuate a dichotomous understanding of First and Third worlds, and an enduring division between 'us' and 'them. ${ }^{.185}$ I suggest that this concept could be applied equally to the issue of poverty.

This ability of NGOs to distort the experiences of those they 'represent' to suit their political aims is also highlighted in a study by Didier Fassin, which examines a humanitarian NGO which also advocates on behalf of the 'victims'. Focusing on the increasing use of human examples to advocate and to encourage political action, he finds that NGOs have the ability, and indeed temptation, to present the realities on the ground in a way that suits the objectives of their advocacy work. ${ }^{186}$ Fassin's study examines the 'significance of a politics of testimony that substitutes its own truth for the truth of those in whose name it is deployed.' ${ }^{187}$ He goes on to reiterate the importance of language by stating that:

the humanitarian workers speak in the name of those who are deemed not to have access to the public arena: they literally speak their words for them. In doing so they illuminate, transform, and simplify these words, dramatise them in line with their objective, which is not so much to reconstitute an experience as to construct a cause. This cause is constructed on the basis of the legitimate principles of humanitarian intervention, the defense of victims, and the appeal to emotion. ${ }^{188}$

He concludes that rather than 'proclaiming the bare truth of the victims... humanitarian testimony constitutes a truth ordeal. It produces utterances having the value of truth that do not reflect the social world but rather transform it. ${ }^{\prime} 189$ In a similar vein, Nyamugasira suggests that NGOs, while claiming to represent the poor, present the issue of poverty in a way that protects the interests of their own social class either unconsciously, or consciously. He also argues that they create their own abstract constituencies of the poor, but are closer in their thinking and to the global elite. ${ }^{190}$

Even if the poor were to learn the dominant language of discourse and thus be included and participate in the debate, there remains the risk of co-option. I suggest that being integrated into a particular community and adopting their language fundamentally changes your thinking. A case in

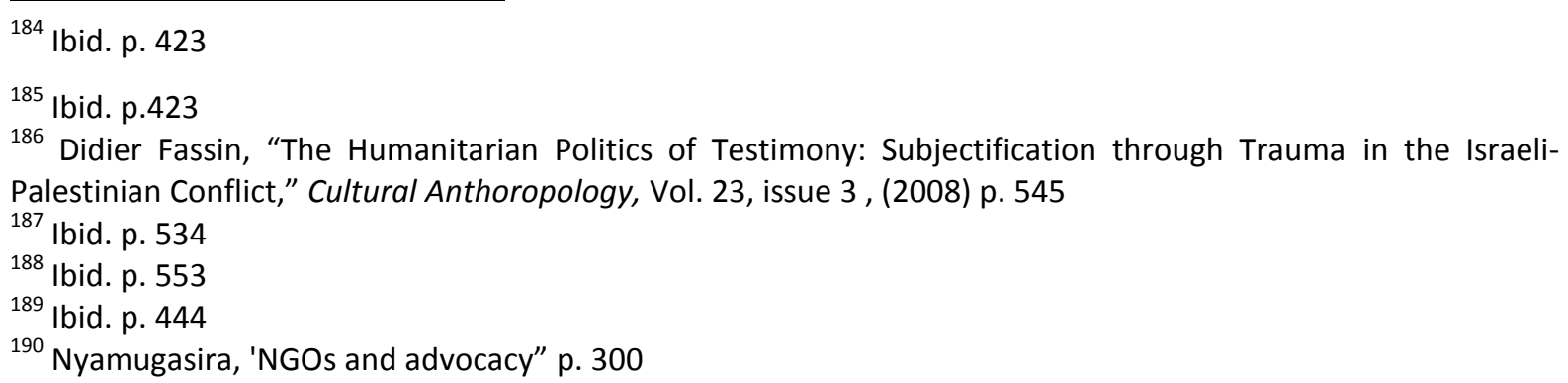


point is illustrated by Cohn, who found that her ability to think from a critical feminist perspective was challenged as result of her involvement as part of a study in the defence sector. Her work suggests that the use of certain terminology restricts the ability to think about an issue in a more analytical manner. As she worked closely alongside professionals in the government defence facility, she found that she quickly adopted a very particular language and mentality that she had originally found absurd and ultimately very disturbing. In other words, she found herself co-opted, the language having transformed her. ${ }^{191}$ This constitutes a restriction upon the ways in which an issue can be discussed and therefore also upon the responses that can be sought and implemented. For NGOs and the poor themselves, it is important to be able to frame the debate in a way that resonates with their experience, and does not transform them away from that experience. This presents a huge challenge given the way the debate has already been framed and the restrictions that have been put in place by the discourse. As Cohn states: '(t)he dominant voice... speaks so loudly in our culture, it will remain difficult for any other voices to be heard until that voice loses some of its power to define what we hear and how we name the world.' 192

The respective relationships of the poor and the elite to the dominant discourse on poverty are comparable to the relationships of the powerless and the powerful to the discourse on power. Edkins noted the importance of language in the latter relationship as exemplified by the abusive nature of states sending their citizens to war.

Abuse by the state, the fatherland, like abuse by the father within the family, cannot be spoken in language, since language comes from and belongs to the family and the community. Survivors of political abuse in the contemporary west have something compelling to say, but it is something that is unsayable in the vocabulary of the powerful, and it is dangerous to the political institutions in place. ${ }^{193}$

I argue that if poverty may be seen as a form of abuse by the state and the international community, the poor have the same challenge in their difficulty of expressing their realities in the language of the powerful elite.

In summary, the power of a UN specific epistemology, the acceptance of an economic focus and an abstract language about the eradication of poverty, together with the monopoly of NGOs in their

${ }^{191}$ Carol Cohn, "Sex and Death in the Rational World of Defense Intellectuals," Signs, Vol. 12, No. 4, (1987), p. 716

192 Ibid. p. 717

${ }^{193}$ Jenny Edkins, Trauma and the Memory of Politics, p. 7 
representation of the poor, results in the further exclusion of people living in poverty from UN processes. This enables choices to be made which can condemn members of a poverty stricken group to suffer devastating consequences, with little political or moral repercussions.

\section{iii. Challenging perceptions about the poor}

The poor have, throughout time, been blamed or pitied, and usually misunderstood. ${ }^{194}$ Charles Booth said that 'the rich hid the poor behind a curtain, and over that curtain, they painted monsters. ${ }^{195}$ I suggest that the lack of participation of people living in poverty at the United Nations represents a missed opportunity to challenge the ingrained perceptions that are widely held amongst elite communities. As noted in an earlier section, it is very confronting to have to think about poverty as being something the citizens of the West have historical responsibility for, and to recognise one's part in the continued suffering. The human instinct to blame the poor for their own situation is well documented. I suggest that it suits the international system for the poor to be excluded and hidden from view - that for the poor to be participants in the UN system, the elites and decision makers would be forced to confront their own prejudices and to finally see the poor as people, parents, partners, workers, rather than as statistics or as subjects who are potentially responsible for their own situations.

The humanity of people living in poverty is often confronting because we are used to abstractions and generalisations. Yet, to actually interact with someone living in poverty can have a strong impact - an impact that I felt time and time again during my work accompanying people living in poverty to the United Nations. To recognise the commonalities between oneself and someone experiencing poverty, whether it be through the shared experience of parenthood and hopes for the future of your children, or something as simple as a shared reflection on the weather; to see the poor finally as individuals, as humans, as capable of expressing their hopes and expectations, can have the effect of reframing the way one thinks about poverty in general. Naomi Hossain notes the uncomfortable experiences that elites may have had with people living in poverty in their lives, and

\footnotetext{
${ }^{194}$ Naomi Hossain, 'Productivity and Virtue:Elite Categories of the Poor in Bangladesh, 'World Development Vol. 33, No. 6, (2005) p. 966

195 Leandro Despouy. "Extreme Poverty and Human Rights at the United Nations", in 'Attacking Extreme Poverty: Learning from the Experiences of the International Movement ATD Fourth World' Quentin Wodon (ed) (World Bank: 2001) p. 133
} 
the impact on how they perceive them. The tendency is to exclude some from the 'poor' category, or to see them as somehow 'exceptional.' 196

It is a common assumption by elites or NGO workers that with the right kind of input and opportunities, the poor will be able to change their situation by realising their economic potential. Another preconception about the poor is that is that the reason for their poverty comes from the nature of them - being a woman, or being disabled, or a child, which is heavily influenced by the common tendency for people to group, to categorise, to explain. Children are rarely judged or blamed for their poverty - however on turning 18 , or as soon as they become parents themselves, this often changes. These perceptions have strongly influenced decision making throughout history because they have enabled judgements about the 'deserving' and non-deserving poor.' ${ }^{197}$ The existence of the 'non-deserving poor' was highlighted by a landmark World Bank study 'Voices of the Poor' which highlighted a category of people who found themselves 'hated' and unable to participate in society. ${ }^{198}$ This category is essentially Wresinski's 'Fourth World' which brings to our attention a group of people who are blamed for their own poverty, unable to use social networks to help themselves and even excluded from poor communities themselves. He described them as being 'forbidden to inhabit the world of others,' ${ }^{199}$ and as seen as unworthy even by their still-poor, but less badly off neighbours.

In his blog posting 'How to write about poor people', ${ }^{200}$ Easterly suggests ten ways to refer to people living in poverty, citing a preference to 'display pictures of poor children (alternatively women)' but not 'show pictures of poor men, who make your audience think of drunkards, wifebeaters, or janjaweed.' Although clearly satirical, these comments highlight the challenges that the poor face in terms of how their situation is perceived by others, particularly by decision-makers and funders. This also highlights the problem that many fundraising NGOs find when representing the poor - that the public's preconception about poverty and instinct to blame the poor for their own situation restricts their ability to communicate. NGOs are important mobilisers of public opinion for efforts to eradicate poverty, and their message may be tailored to fit with people's perceptions, hence the frequent use of images of women and children in fundraising literature. This form of representation highlights a dilemma; the poverty eradication discourse depends upon public support

\footnotetext{
${ }^{196}$ Hossain, "Productivity and Virtue" p.969

197 Ibid. p. 967

198 Ibid. p.969

${ }^{199}$ Wresinski, "The Very Poor, Living Proof of the Indivisibility of Human Rights" p. 2

${ }^{200}$ William Easterly, 'How to Write about Poor People' http://aidwatchers.com/2009/12/how-to-write-aboutpoor-people-contd-the-interactive-edition/ (accessed February 14, 2010)
} 
and political will. There is, therefore, an incentive to paint the poor as simple and needy in order to appeal to people's emotions and thereby raise funds. This is more effective than portraying the poor as people with human flaws and complicated lives. I suggest that the way NGOs represent the poor to the public is continued through to the United Nations. This is potentially devastating as 'the ability of the poorest and their agents to represent themselves to political elites as deserving remains critical to the effective relief of material poverty. ${ }^{201}$ Therefore, an inaccurate perception is dangerous in terms of the ability of the poor to muster political will and accept them as participants in high level debates.

The inclination to identify reasons for poverty by implicating the poor themselves is also pervasive. Neo-liberal thinking has been very influential in perpetuating certain perceptions, with a tendency to address the problem of increase of poverty by 'disconnect(ing) the social problem from its systemic roots and attempt(ing) to identify poverty with individual ethics - "work" or "entrepreneurial spirit."202 This, in effect, puts blame on the poor and creates an expectation that with hard work, they should be able to overcome their own poverty. If people living in poverty were invited to participate in UN discussions and could share their experiences of how hard they really work, and show how the efforts they make to improve their situation meet with constant systemic barriers, a greater awareness of the structural barriers that keep people and countries in poverty could be created. However, the possibility of this happening remains slight. As Leondro Despouy, an expert on human rights who has held numerous positions at the United Nations and has worked to represent the interests of the poor contends:

It is often more difficult to prove what is apparent than what is unique or exotic.... One of the main challenges I had to face as Special Rapporteur on this issue was, precisely, avoiding that my commitment and faithfulness to the portrayal of poverty... would betray the message and reality of those living under extreme poverty conditions. How can one describe truthfully the miserable living conditions, the suffering and, above all, the degradation poverty causes on individuals without resorting to fatalist messages in the sense that people who have become impoverished would never be able to escape from it, or even worse, that degradation has been such that these individuals have already lost their status as human beings, without unwillingly contributing to racist of xenophobic biases?

\footnotetext{
${ }^{201}$ Bracking and Hickey, "Exploring the Politics of Chronic Poverty" p. 859

202 James Petras, 'Alternatives to Neoliberalism in Latin America', Latin American Perspectives, no. 24 (1997) p. 89
} 
How can one show the terrible aspects of poverty without playing the card of those that have a discriminatory perception of the poor? ${ }^{203}$

He goes on to say that:

One of the most important contributions of the study on extreme poverty and human rights was to show how little we know about extreme poverty. Aside from being deficient, our knowledge is often wrong, since the perception of poverty in our societies is mostly derogatory and full of biases. ${ }^{204}$

I argue that this inability to faithfully communicate the harsh realities of poverty without perpetuating the stereotypes of the poor makes participation of people living in poverty at the United Nations even more urgent. In their absence the issue of poverty is repeatedly misconstrued.

Subscribing to the idea that those in power should have the chance to meet with people living in poverty and that personal contact would challenge preconceptions about poverty and stimulate action, International Movement ATD Fourth World organises regular high level events between people living in poverty and decision makers. I co-organised and attended meetings between two UN Secretaries General (UNSG) and people living in poverty from various countries, North and South. My personal and subjective recollection is that each meeting had positive outcomes. In particular, it was beneficial for the UNSGs to hear the firsthand accounts of people living in poverty in their office environment, rather than surrounded by destitution, as is often the case with visits to the poor. In one of the meetings, the UNSG clearly started paying attention when a woman started to tell her story of what it is like to live in poverty. I perceived that, as part of a long day filled with a series of meetings with officials, her statement stood out and was listened to intently. The UNSG then accepted a challenge from Aling Tita Villarosa from the Philippines to partner with the poorest in the international efforts to eradicate poverty. During a meeting with another UNSG, he told personal stories of the challenges of his childhood, and exchanged with the delegates on a very informal basis. While it is impossible to measure the actual outcomes of such encounters within the confines of this thesis, I feel confident that such personal interactions had a positive effect on the high level understanding of the issue of poverty.

These subjective impressions of the positive experiences that resulted from meetings between people living in poverty and the UNSGs are substantiated in a study by Bruno Tardieu and Jona Rosenfeld who discovered that interaction with people living in poverty can change the perceptions

\footnotetext{
203 Leandro Despouy. "Extreme Poverty and Human Rights at the United Nations", in 'Attacking Extreme Poverty" p. 133

204 Ibid.
} 
of people in power. They found that by bringing professionals from institutions and people living in poverty together to engage in simple activities, they created an environment in which the preconceptions of both sides were challenged. Even though the professionals may have met people living in poverty before, encounters such as these which brought them together at 'eye level,' often changed their outlook, and enabled them to see the people living in poverty as people, not problems. One participant said '(e)lsewhere I would have seen only the undone hem, there I saw the woman. 205

The Draft Guiding Principles on Extreme Poverty and Human Rights is another initiative that worked under the assumption that interaction between decision makers and people living in poverty would positively impact policy decisions. In 2001, the United Nations Sub-Commission on the Promotion and Protection of Human Rights requested that a group of independent experts develop a document that addressed the issue of extreme poverty within the human rights framework. International Movement ATD Fourth World facilitated interaction between the experts and people living in poverty, organising a series of meetings at which they could exchange views and relate at a personal level. The result was a set of principles which had the views of the participating families at its core. The experts have since incorporated wording into the resulting documents that reinforce the importance of consulting with the poor themselves.

However, personal accounts - also known as testimonies - where people living in poverty are given the opportunity to speak out about their experiences and to share their efforts to overcome poverty are often hard to hear. The impact of these statements is evidenced by the feedback from NGO partners after each commemoration of the International Day for the Eradication of Poverty, which overwhelmingly focus upon the power of testimonies. Testimonies are often confronting, and challenge people to re-examine their perceptions about poverty and dignity. A particularly poignant example occurred at the International Day for the Eradication of Poverty in 2005, when an ATD Fourth World delegate emphasised the dignity inherent in her work sorting recyclables from rubbish in a dump in her home town in Latin America. Because her work supported and enabled her children to go to school, she derived huge pride and dignity from it. Such testimony, I attest, has the potential to change perceptions and to prompt political will.

\footnotetext{
${ }^{205}$ Bruno Tardieu and Jona Rosenfeld "Artisans of Democracy: How Ordinary People, families in extreme poverty and social institutions become allies to overcome social exclusion" (Maryland, University Press of America 2000) p.215
} 


\section{iv. The power of testimony to prompt political will}

Poverty persists because it is politically acceptable. Enough wealth exists in order for everyone's basic human needs to be satisfied. The fact that the world's governments have not even met their limited financial commitments in this area is testament to the lack of political will to end poverty. This continues irrespective of governments' persistent rhetoric, which suggests otherwise. As a group that have limited political power and little voice the poor are, by definition, denied meaningful access to their civil and political rights, and therefore their economic and social rights. Whether they are, as I argued earlier, subsumed into other interest groups, dismissed as too preoccupied with survival to participate in the development of poverty eradication policy, or disregarded as being unable to understand the technical nature of the debate, they are usually absent, and easily ignored by the international political elite. I further argue that there is a persistent political facade that dominates the discourse at the UN. The systematic and genuine participation and testimony of people living in poverty at the United Nations has the potential to expose that facade and make the eradication of poverty a moral and political imperative.

The persistence of abject poverty in a world of abundance is an appalling injustice. Every 3 seconds, a child dies of a preventable poverty-related disease, and generation after generation grow up without any realistic hope of a more secure life than their parents'. The international community collectively spends more on arms than on poverty alleviation. Children do not die because their parents are lazy or because their parents do not care - they die because of an appalling and stark inequality in the world and the lack of political will to address it. International emergencies such as terrorist attacks, airplane crashes or earthquakes result in much soul searching and changes to ensure it never happens again. Action is immediately taken - political will is mobilised to prevent repeats. As a society we have constructed mourning, tragedy, the idea of what is terrible and what is acceptable. ${ }^{206}$ We visit and leave flowers for people who died fighting wars generations ago. Yet we also allow our governments to make decisions about trade and ODA that keep millions in poverty and allow thousands of preventable deaths to occur daily. We have created a political smokescreen so we do not have to cope with such a traumatic reality.

I suggest that the persistence of poverty is an ongoing trauma, one as appalling as the loss of life experienced in the terror attacks of $9 / 11$, the historical wars, the various genocides. But as it is ongoing and constant, it has ceased to be a catalyst for political action. The elites and decision makers are able to abstract it and separate it from their lives in the understanding that it is unlikely

\footnotetext{
${ }^{206}$ Edkins, Trauma and the Memory of Politics, p. 7 and p. 3
} 
to personally touch them. Therefore the issue of poverty does not garner the political will and action it deserves proportionate to the body count. I believe that regular and meaningful participation of people living in poverty at the UN, and the sharing of their testimonies of the reality of their lives will result in increased political will, and action.

The issue of poverty is a political construct, one which has become acceptable to neglect as nonurgent. The poor are seen as non-threatening until they become an actual threat and need to be managed with force, a scenario the world witnessed (albeit from afar in many cases) during the food riots in 2009. ${ }^{207}$ Hossain argues that in Bangladesh, the perception of the poor as virtuous, and a weak threat, has led to a lack of prioritisation of action on poverty. ${ }^{208}$

I suggest that the continuation of the poverty debate using abstract terms and political rhetoric would be severely challenged if the poor were to have a meaningful and regular place in the United Nations debate. Their regular presence at the UN has the potential to expose the reality behind the rhetoric. To use Zizek's phrase, the reality of testimony would force the decision makers to visit 'the desert of the real, ${ }^{209}$ finally piercing the facade that allows politicians to continue making decisions as if there is no urgency, no emergency, no disaster despite the millions of people that are dying needlessly because of inaction. To be confronted with the reality of testimony on a regular basis would render it impossible for them to harbour the illusion that 'we the people' have come together to advance the economic and social wellbeing of everyone. Instead, the social world, in its current form, is fundamentally unjust; economic growth is not the answer alone, people continue to starve, die and lose their children to preventable causes. The world is in fact, a 'staged fake ${ }^{210}$ where those in affluent industrialised countries are able to avoid thinking about the living conditions of those who produce their cheap consumer goods and the probability that their governments' inaction or action is condemning people to poverty in order to preserve the affluence of their own communities. As Žižek states: 'The ultimate truth of the capitalist utilitarian despiritualised universe is the dematerialization of the "real life" itself, its reversal into a spectral show. ${ }^{211}$

Drawing on the terrorist attacks of 9/11 2001 in the USA, Zizek argues that the event was so shocking because the US had to recognise the reality of their place in the world, and were forced to encounter the 'barbarian outside'. I suggest that the same has the potential to occur with the reality

\footnotetext{
${ }^{207}$ Eugen Brand, 'Hunger for Bread, Hunger for Roses'

${ }^{208}$ Hossain, "Productivity and Virtue" p. 974

${ }^{209}$ Slavoj Žižek, "Welcome to the Desert of the Real!" The South Atlantic Quarterly 101: 2, (Spring 2002), p. 386

210 Ibid.

211 Ibid.
} 
of extreme poverty. If decision makers are to be confronted on a regular basis with people living in poverty, they will find it no longer possible to live within a 'staged fake.'

Once the powerful experience the humanity of the poor and the enormity of the numbers of their deaths, would memorials be built? In today's society, memorials have taken on a huge importance - they play a significant role in the way trauma is incorporated into the narrative of societal history. ${ }^{212}$ There is always someone to visit them, to pay tribute to the victims of traumatic events. However, forgetting is also pivotal. In order for politics to continue, a linear political narrative must be accepted, and anything that does not fit into that narrative must be rejected or ignored. ${ }^{213}$ So in modern politics the poor are not recognised, not seen as having died for anything, because of anything. If we were to memorialise them, we would be forced to confront our own implication in their deaths, and to recognise that we had the power to condemn people to remain in poverty - the power to 'make live and let die. ${ }^{214}$ We have memorialised the historical poor - a memorial to those who died during the Irish famine stands in the UN gardens - but not the ongoing poverty that exists today. If we can't find a reason (that doesn't implicate us) and we can't find someone else to blame - how can we erect memorials? How could we memorialise those who have died from poverty while we continue to enjoy affluence? I suggest that to do so would force us into the 'desert of the real. ${ }^{215}$

To acknowledge the present suffering of poverty would force decision makers to confront their own involvement in such suffering. Schick cuts to the heart of the vulnerability that decision makers are confronted with when she summarises Edkins' idea that

\begin{abstract}
traumatic events signal the traumatic real that lies beneath the secure facade of contemporary politics, pointing to the violence that created and maintains the international state system and to its profound fragility. As a result, sovereign states have a vested interest in silencing the voices of those who have suffered. ${ }^{216}$
\end{abstract}

\footnotetext{
212 Edkins, Trauma and the Memory of Politics p. 229

${ }^{213}$ Ibid. p. 229

214 Mark Duffield, "Development, Territories, and People: Consolidating the External Sovereign Frontier" Alternatives: Global, Local, Political, Vol 32 Iss 2, (2007) p. 237

${ }^{215}$ Žižek "Welcome to the Desert of the Real!" p.386

${ }^{216}$ Kate Schick, "To Lend a Voice to Suffering is a Condition for all Truth: Adorno and International Political Thought" Journal of International Political Theory, Vol. 5, Issue 2, (2009) p. 140
} 
Decision makers can easily dismiss such reality from inside the 'staged fake', simply by reiterating the importance of guarding against emotion and adhering to protocol, with such comments as

an intergovernmental political forum such as us can only handle what can be handled. Politics is the art of the possible. We organise our work, we focus it within rules of procedure, within a context, within systems with an insistence for human conviviality. Good neighbourliness is ruled by law and rules of behaviour. ${ }^{217}$

This justification for the dismissal of testimonies or interventions from people with experience of poverty was to perceive them as akin to therapy sessions. As Finnemore and Sikkink note, 'emotions can be politically dangerous and undesirable in politics; hate after all is affect too. ${ }^{218}$ However, the poor must be present - this facade must be broken down, and that can only be done if they lead the way.

\section{v. The poor must be leaders of their own liberation and reclaim their dignity}

In the absence of political will, it is imperative that the struggle against poverty must be lead by the poor themselves. Freire's main concepts around liberation from oppression provide a further justification for the participation of people living in poverty at the highest level of politics - the United Nations. Certainly, seeing the poor through the lens of oppression is justified as they cannot be seen to be free - human rights in their totality have been denied to them, meaning they are unable to be full participants in society. ${ }^{219}$ Wresinski also notes that extreme poverty means they are unable to assume their rights and responsibilities, including the right to participate in society. ${ }^{220}$

Friere argues that those who are not oppressed are unable to lead the struggle for freedom. The oppressed 'must, from their stifled humanity, wage for both the struggle for a fuller humanity; the

\footnotetext{
${ }^{217}$ Informal Hearings of the General Assembly with non-governmental organisations, civil society organisations and the private sector, UN Webcast Freedom from Fear, 24 June, 2005, (transcribed by author) http://www.un.org/ga/civilsocietyhearings/webcast.html (accessed March 15, 2010)

${ }^{218}$ Martha Finnemore and Kathryn Sikkink, "International Norm Dynamics and Political Change" International Organization, Vol. 52, No. 4, (1998) p.916

${ }^{219}$ Amnesty International affirms this in their Dignity Campaign - extreme poverty is both a cause and consequence of human rights violations. Additionally, the Draft Guiding Principles on Human Rights and Extreme Poverty and several and resolutions assert this.

${ }^{220}$ Wresinski, "The Very Poor, Living Proof of the Indivisibility of Human Rights", p. 5
} 
oppressor, who is himself dehumanized because he dehumanises others, is unable to lead this struggle.' ${ }^{221}$ Wresinski concurs, noting that the poor are actors in their own liberation but are rarely seen as such, because they hide from the oppressor. Arguing for a different way of looking at the poor, he suggests that the non-poor make dangerous assumptions about the capabilities of those living in poverty.

Those who think that human beings reduced to total poverty are apathetic and consequently don't think, that they retreat into dependency or the simple struggle to survive day to day, make a serious mistake. They ignore the strategies of self defense that the poor create to escape the influence of those on whom they are dependent. They protect their own existence, which they carefully hide behind the "life" that they spread out like a curtain and "play" to create an illusion for the external observer. Finally, they ignore the desperate effort to reflect and explain of those who constantly ask themselves, "Just who am I, after all?" or who say, "They treat me like a dog, like a spineless coward, an idiot, a non-entity. . . . Am I really a spineless coward?" And there are those who through a painful effort of thinking constantly rise up from under their own personalities and those accusations which are so many monstrous identities heaped upon them by repeating to themselves, "But I am not a dog. I am not the idiot I am made out to be. I know things, but they will never understand."222

Despouy also recognises the hidden realities of the efforts of the poor when he writes of the acts of solidarity that are evident within communities living in poverty.

These are gestures that define a willingness to fight, even when the fight materialises in small achievements, scarce successes and many defeats. But these successes - which may seem insignificant in light of those countless battles that are lost daily - state in their own way (and in the wordless language of those who most of the time have not even learned to use these words), the reality of a fight, or a silent and unseen struggle whose intensity and resilience allowed the very poor to face their condition each day and at each moment of their lives. Without an acknowledgement of the efforts of the poor and those who support them, it would be difficult to contribute to the liberation from poverty. ${ }^{223}$

\footnotetext{
${ }^{221}$ Freire, Pedagogy of the Oppressed, p.29

${ }^{222}$ Wresinski, 'A Knowledge that Leads to Action', p, 4

${ }^{223}$ Leandro Despouy, "Extreme Poverty and Human Rights at the United Nations", in "Attacking Extreme Poverty' p. 134
} 
Until people living in poverty are given the opportunity to be leaders of their liberation, they will be unable to break free. If, as Freire argues, to liberate oneself from oppression is an act of love for the oppressor as it gives the oppressor back their humanity, surely the decision makers of the UN deserve the opportunity to benefit from such intervention? Why should they not be given the opportunity to see the poor as they are, to benefit from seeing their humanity, and thus be given a genuine opportunity to eradicate poverty?

I was involved intimately with the making of space for people living in poverty to speak at various events at the UN and can share anecdotally the immediate impacts of such opportunities for participation. A long-time member of International Movement ATD Fourth World, Miss Gemma Speaks, talking about her participation in many commemorations of the International Day for the Eradication of Poverty at the UN, said 'The first time you speak at the UN, a kind of dignity falls from the sky and that never leaves you.' For her, the opportunity to speak at such an institution enhanced her dignity, in spite of her experience of poverty.

Other members of ATD Fourth World recounted similar experiences after a delegation, following two years of organising and advocacy, secured an appointment with the UNSG on the International Day for the Eradication of Poverty. I spent considerable time with one of the delegates, and she told of how she left a community of people behind to travel to New York, and how hard that was because her community needed her. She had to face the potential humiliation of having her visa refused $^{224}$ and the fear of having tragedy strike her fragile family and community in her absence. ${ }^{225}$ During the meeting, she was able to put forward her hopes for efforts to eradicate poverty to involve the poor themselves, a point that was clearly listen to by the UNSG. After the meeting, when I asked her how she felt it went, she said 'that wasn't a waste of time'. What is most striking to me is that this woman, who lived in such a vulnerable situation, should recognise the value of her own time and life so much that she could consider meeting the UNSG potentially a waste of time. She did not travel to New York for the meeting in order to seek status; rather, she did it to make a contribution to the international efforts to fight poverty. She had something to give to the cause and she felt able to give it, despite the personal risks to herself.

\footnotetext{
${ }^{224}$ One of the considerations of many countries when issuing visas is the ties of applicants to their home countries, in particular financial ties. For people living in poverty who have few assets and sometimes no formal employment, they are at higher risk of having their travel visas refused. This was often the case for delegates travelling to speak at the UN.

225 Many living in poverty, especially in developing countries have vulnerable lives to do with housing, exposure to the elements, illnesses etc.
} 
Many of the people that I worked with who were living in poverty had a similar, genuine conviction that by speaking directly to those in power, they could make a difference - that they could actually create change and convince the powerful to act with urgency and in partnership with the poor. Freire's words ring true when faced with the generosity of the poor who risk so much to give their testimony before the international political elite that act as their oppressors. This resonates for me when I think of my friend and colleague, who was willing to contribute her experience and her expertise to the fight against poverty. I argue that more of her peers should also be given that opportunity. 


\section{Conclusion}

This thesis concludes that people living in poverty must have a regular space at the United Nations which values their indispensible experiences and perspectives. Only then can the discourse around the eradication of poverty be truly legitimate.

The United Nations is the main seat of the contemporary debate, the leader in the development of global policy, and the engine for driving the political will to eradicate poverty. I have argued that in spite of increasing rhetoric about the importance of participation, the poor are largely absent from the discussions at the UN. This in part results from the situating of such participation primarily at the local level, in contrast with other identity groups, who have fought hard for, and been granted, a space at the UN. I have argued that NGOs should support people who are living in poverty to speak for themselves and to take their rightful space in the debate in order to alter the discourse on poverty. In so doing they would be able to follow the footsteps of other identity groups such as women, people with disabilities, and indigenous peoples. Not only would this partially fulfil the human right to participation for this marginalised group, it has the potential to advance the global goal of poverty eradication.

The poor are either subsumed into other identity groups, or the NGO community is seen as their legitimate representatives, a situation which NGOs are on the whole content to maintain and reproduce. However, such representation presents serious problems, and these NGOs are made complicit in the continued marginalisation of those who they purport to represent. They do so by replacing them in the debates; through the frequent combination of charity and advocacy, which means that the poor are less likely to freely express their views to their NGO representatives; a lack of local political awareness such that local participation frequently reproduces the existing local power dynamics; and the absence of, and unwillingness to hear, the very poorest in such consultations. Furthermore, when the poor are able to express their opinions, NGOs are adept at adjusting these views in order to fit their advocacy goals, highlighting the problem with representation at high level debates.

The most influential advocacy NGOs are those that are centralised and professionally staffed, meaning that they are less likely to be close to those they represent. Furthermore, the common assumption that Southern NGOs are closer to the poor is not necessarily true. Some Southern NGOs tend to have more in common with the elite of the Global North than the poor of the Global South. This is particularly the case when the organisation has a hierarchical structure and its 
representatives are professionals based in Northern centres. What is needed is a greater consideration of the organisational structure of NGOs rather than simply their regional origins. Membership based organisations of the poor tend to be more representative.

In the second section, I argued that the issue of poverty is in fact a global emergency, resulting in millions of needless deaths and ongoing, intergenerational suffering. However, in its treatment as an emergency by the UN through the use of statistics and biopower, the resulting abstraction and dehumanisation of the poor means it has escaped the urgent political action with which other emergencies are addressed. The debate around poverty is currently framed by the use of technical, economic-based language and procedural norms, both of which restrict the range of possible solutions as well as exclude people living in poverty from genuine participation. The decisions that are made at the international level are made within a political bubble, with procedure and formalities reproducing the exclusion of unmanageable emotion and realities of the lives of people living in poverty. By actively managing the debates and abstracting the issue, decision makers are able to separate themselves from the potentially devastating outcomes of their decisions. I argue that a regular, genuine presence of the poor at the United Nations has the potential to expose the reality and the fragility of the international political facade, forcing decision makers to recognise the humanity of people living in poverty and consider the true impacts of their action or inaction. I do not believe that the marginalisation of the poor is done maliciously; rather it results from a lack of understanding of the realities of the lives of the poor. This must be rectified, and participation of the poor has the potential to increase such understanding.

Although the UN elites have a vested interest in silencing the poor, they are already there. Already some NGOs have taken up the challenge to ensure that people living in poverty have a space at the United Nations. Through such events as the commemoration of the International Day for the Eradication of Poverty and by meeting high level decision makers, the poor do claim their space, making an indelible impact on many who hear them speak. However, those who work to regularise and institutionalise such participation face a constant need to restate the argument and to recreate such spaces. The energy that is expended in this process, and the obvious push-back that is seen and felt by those who seek to participate, has the effect of further marginalising people living in poverty, telling them again that their voice counts for nothing and that their knowledge is not valid. To quote Freire, the poor are told that 'they are good for nothing, know nothing, and are incapable of learning anything. ${ }^{226}$ The United Nations has an opportunity to demonstrate to the poor that their expertise

${ }^{226}$ Freire, Pedagogy of the Oppressed, p. 45 
and experiences are valued, and that they recognise them as the agents of change that they have always been. In so doing, they will also be spreading dignity to others - allowing the poor to reclaim their dignity and lead their own liberation. Such a move would also allow the elites to share in that dignity, to stop marginalising and dehumanising the poor, and to in turn, reclaim their own humanity. 


\section{References}

ATD Fourth World. Reaching the Poorest. Paris: Editions Quart Monde, 1996

Barry, Christian and Pogge, Thomas (eds.) Global Institutions and Responsibilities; Achieving Global Justice.

Oxford: Blackwell Publishing, 2005.

Botes, Lucius and van Rensburg. Dingie.“Community participation in development: nine plagues and twelve commandments." Community Development Journal: Iss 35, Vol. 1, (Jan 2000): 41-58

Bracking, Sarah and Hickey, Sam. "Exploring the Politics of Chronic Poverty: From Representation to a Politics of Justice?" World Development, Vol. 33, No. 6 (2005): 851-865

Brand, Eugen. "Hunger for Bread, Hunger for Roses", http://www.atdfourthworld.org/Hunger-for-Bread-Hunger-for-roses.html?var recherche=bread\%20, (accessed September 19, 2009)

Carbert, Anne and Rioux, Marcia. "Human Rights and Disability: The International Context," Journal of Developmental Disabilities, Vol. 10, No. 2 (2003): 1-14

Chan, Elizabeth, "The Politics of Aid." NZ International Review, Vol. 35 (2010) pp. 17-24

Charter of the United Nations and Statute of the International Court of Justice, (1945) http://www.un.org/en/documents/charter/ (accessed March 19, 2010)

Charters, Claire. 'A Self-Determination Approach to Justifying Indigenous Peoples' Participation in International Law and Policy Making', presented at 'We the People(s)' 2010 Conference, Wellington

Chen, Martha et al (eds.) Membership Based Organisations of the Poor. Oxon: Routledge, 2007

Cohn, Carol. "Sex and Death in the Rational World of Defense Intellectuals." Signs, Vol. 12, No. 4, (Summer, 1987): $687-718$

Collier, Paul. The Bottom Billion. New York: Oxford University Press, 2007

Conference of NGOs in Consultative Status with the United Nations, 'Introduction' http://www.ngocongo.org/about (accessed March 18, 2010) 
Craig, David and Porter, Doug. "Poverty Reduction Strategy Papers; A New Convergence." World Development, Vol. 31, No. 1 (2003): 53-69

Despouy, Leandro. Final Report on Human Rights and Extreme Poverty, United Nations Commission on Human Rights (1996) E/CN.4/Sub.2/1996/13

Dearden, Nick. “From charity to solidarity.“Globalizations, Vol. 3, Issue 2, (2006): 261-263

Dillon, Michael. "Governing Terror: The State of Emergency of Biopolitical Emergence." International Political Sociology, 1, (2007): 7-28

Dube, S C. Modernization and Development: the Search for Alternative Paradigms. London: Zed Books, 1988

Duffield, Mark. "Development, Territories, and People: Consolidating the External Sovereign Frontier." Alternatives: Global, Local, Political, Vol 32 Iss 2 (2007): 225-246

Edelman, $\mathrm{M}$ and Haugerud, A (eds.) The Anthropology of Development and Globalization: From Classical Political Economy to Contemporary Neoliberalism. Oxford: Blackwell, 2005

Edkins, Jenny. Trauma and the Memory of Politics. Cambridge: Cambridge University Press, 2003

Edkins, Jenny. "Biopolitics, Communication and Global Governance." Review of International Studies, 34, (2008): 211-232

Edwards, Michael. "The Irrelevance of Development Studies." Third World Quarterly, Vol 11, No 1 (Jan 1989): 116-135

Easterly, William, 'How to Write about Poor People' http://aidwatchers.com/2009/12/how-to-write-aboutpoor-people-contd-the-interactive-edition/ (accessed February 14, 2010)

Farmer, Paul. Pathologies of Power, Health, Human Rights, and the New War on the Poor. London: University of California Press, 2005

Fassin, Didier, "The Humanitarian Politics of Testimony: Subjectification through Trauma in the IsraeliPalestinian Conflict." Cultural Anthoropology, Vol. 23, Iss. 3 (2008): 531-558

Finnemore, Martha and Sikkink, Kathryn. "International Norm Dynamics and Political Change." International Organization, Vol. 52, No. 4, (1998): 887-917 
Foresti, Marta, et al, Overseas 'Development Institute, Project Briefing 34', (January 2010)

Francis, Paul and James, Robert. "Balancing Rural Poverty reduction and Citizen Participation: The Contradictions of Uganda's Decentralization Program." World Development, Vol. 31, No. 2 (2003): $325-337$

Freire, Paolo. Pedagogy of the Oppressed. London: Penguin, 1996

GCAP ‘Poverty Hearings and Women's Tribunals 2008' http://www.whiteband.org/Action/materials/gcappublications-and-booklets/gcap-poverty-hearings-and-womens-tribunals-2008 (accessed March 28, 2008)

GCAP 'Poverty Hearings in New York' http://www.whiteband.org/blog/archive/2008/09/23/povertyhearing-in-new-york (accessed 15 March 2010)

GCAP, Email to GCAP's members, "GCAP invited to be a member of Task Force of President of the General Assembly to organise CSO interactive hearings', 8 March 2010

Godinot, Xavier. Eradiquer la misere: Démocratie, mondialisation et droits de l'homme. Presses Universitaires de France, Paris: 2007 (English translation awaiting publication)

Green, Duncan. From Poverty to Power; How active Citizens and Effective States can Change the World. Oxford, UK: Oxfam International, 2008

Hattori, Tomohisa. "The Moral Politics of Foreign Aid." Review of International Studies. Vol. 29, no 2 (April 2003): 229-247

Hossain, Naomi "Productivity and Virtue: Elite Categories of the Poor in Bangladesh." World Development Vol. 33, No. 6 (2005): 965-977

International Movement ATD Fourth World 'Turning Rhetoric into Action: Building effective partnerships to combat extreme poverty and exclusion,' (New York: 2008)

Jordan, Bill. A Theory of Poverty and Social Exclusion. Cambridge, USA: Polity Press, 1996

Kanter, Arlene. "The Promise and Challenge of the United Nations Convention on the Rights of Persons with Disabilities." Syracuse Journal of International Law and Commerce, Vol. 34 (2007): 287 -321 
Lander, Dorothy. "Writing as witness: Doing justice to participants' testimony" Adult Learning. Vol. 12, Iss. 3 (Summer 2001): 17-19

Linklater, Andrew. "Toward a Sociology of Global Morals with an Emancipatory Intent"' Review of International Studies, 33, (2007): 135-150

McKoen, Nora, and Kalafatic, Carol, Strengthening Dialogue: UN Experience with Small Farmer Organisation and Indigenous Peoples. New York: NGLS United Nations, 2009

Martens, Kerstin. NGOs and the United Nations; Institutionalisation, Professionalisation and Adaptation. Palgrave McMillan: Hampshire, UK, 2005

Millennium+5 NGO Network 'We Will Spare No Effort: A Civil Society Call to Action for the Five Year Review of the Millennium Summit and the Millennium Development Goals' June 2005 http://www.ngocongo.org/index.php?what=resources\&id=326 (accessed April 28, 2010)

Millennium Challenge Corporation. 'Selection Criteria' http://www.mcc.gov/mcc/selection/index.shtml, (accessed March 19, 2010)

Mohan, Giles and Stokke, Kristian. "Participatory Development and Empowerment: The Dangers of Localism." Third World Quarterly, Vol. 21, No. 2 (2000): 247-268

New York University. $\quad$ / Easterly Sachs Debates' http://www.nyu.edu/fas/institute/dri/Easterly/SachsDebates.htm (accessed March 28, 2010)

Nyamugasira, Warren. "NGOs and Advocacy: how well are the poor represented?" Development in Practice, Vol. 8 (1998): 297-308.

Petras, James. "Alternatives to Neoliberalism in Latin America." Latin American Perspectives, no. 24, (1997): 80-91

Pogge, Thomas and Reddy, Sanjay. 'How not to count the poor! A reply to Ravallion', August 15, 2002. http://www.columbia.edu/ sr793/poggereddyreply.pdf (accessed January 4, 2010)

Pogge, Thomas. "The First United Nations Millennium Development Goal: a cause for celebration?" Journal of Human Development Vol. 5, No. 3 (2004): 377-397

Pogge, Thomas (ed.) Freedom from Poverty as a Human Right; Who owes what to the very poor?' Oxford: Oxford University Press, 2007 
Pogge, Thomas (ed.) 'Global Justice,' Oxford: Blackwell Publishing, 2001

Pogge, Thomas. John Rawls, 'His Life and Theory of Justice. Oxford: Oxford University Press, 2007

Polak, Paul. Out of Poverty; What works when traditional Approaches Fail. San Fransisco: Berret-Koehler Publishers, 2008

Schick, Kate. "To Lend a Voice to Suffering is a Condition for all Truth: Adorno and International Political Thought." Journal of International Political Theory, Vol. 5, Iss 2 (2009): 138-160

Skard, Torild. "Gender in the Malestream - Acceptance of Women and Gender Equality in Different United Nations Organisations." Forum for Development Studies Vol. 36, Iss. 1 (2009): 155 -191

Somberg, Ben. "The World's Most Generous Misers: Tsunami reporting misrepresented U.S. giving." September/October 2005, www.fair.org/index.php?page=2676 , (accessed March 20, 2010)

Stedman Jones, Gareth, An End to Poverty? London: Profile Books, 2004

Storey D, Bulloch H and Overton J, "The Poverty Consensus: Some Limitations of the Popular Agenda." Progress in Development Studies, Vol.5, Iss. 1, (2005): 30-44

UNICEF. Press release 'Global child mortality continues to drop' New York, 10 September 2009 http://www.unicef.org/media/media 51087.html (accessed March 2, 2010)

United Nations Commission for Social Development, 'Report on the forty-fifth session, E/2007/26' (2007) http://www.un.org/esa/socdev/csd/2007/documents/final-report-eng.pdf (accessed March 28, 2010)

United Nations CSO Net Civil Society Network, 'Civil Society Participation Statistics 2009', http://esango.un.org/irene/index.html?page=static\&content=stats (accessed April 18, 2010

United Nations Department of Economic and Social Affairs, 'Strengthening Efforts to Eradicate Poverty and Hunger: Dialogues at the Economic and Social Council', http://www.un.org/en/ecosoc/docs/pdfs/0749285-ECOSOC-Book-2007.pdf (accessed 15 March 2010)

United Nations Department of Economic and Social Affairs 'International Day of Cooperatives' www.un.org/esa/socdev/social/intldays/IntlCoops/ (accessed March 22, 2010)

United Nations Department of Economic and Social Affairs NGO Branch. 'Apply for Consultative Status' http://esango.un.org/paperless/Web?page=static\&content=apply 
United Nations Department of Economic and Social Affairs, Office for ECOSOC Support and Coordination.

'Strengthening Efforts to Eradicate Poverty and Hunger: Dialogues at the Economic and Social Council' (United Nations New York: United Nations, 2007)

United Nations Department of Economic and Social Affairs NGO Branch. 'What is ECOSOC Consultative Status' http://www.un.org/esa/coordination/ngo/ (accessed March 28, 2010)

United Nations Development Programme. Human Development Report. United Nations:1994

United Nations Division for the Advancement of Women, 'Registration for the Commission on the Status of Women 2010' http://www.un.org/womenwatch/daw/csw/NGO.html\#parallel (accessed February $17,2010)$

United Nations Division for the Advancement of Women, 'Short History of the Commission on the Status of Women', http://www.un.org/womenwatch/daw/csw/index.html\#about (accessed March 15 2010)

United Nations Enable http://www.un.org/disabilities/default.asp?id=33 (accessed March 15 2010)

United Nations General Assembly Resolution 51/178, First United Nations Decade for the Eradication of Poverty, http://www.un.org/documents/ga/res/51/ares51-178.htm (accessed March 28, 2010)

United Nations, A/58/817, (June 2004) 'We the peoples: civil society, the United Nations and global governance. Report of the Panel of Eminent Persons on United Nations-Civil Society Relations' (Cardoso Report) http://daccess-ddsny.un.org/doc/UNDOC/GEN/N04/376/41/PDF/N0437641.pdf?OpenElement (accessed March 28, 2010)

United Nations Millennium Declaration, General Assembly Resolution 55/2, (2000) http://www.un.org/millennium/declaration/ares552e.htm (accessed March 28, 2010)

United Nations General Assembly Resolution 62/205. Second United Nations Decade for the Eradication of Poverty (2008-2017) http://daccess-ddsny.un.org/doc/UNDOC/GEN/N07/476/07/PDF/N0747607.pdf?OpenElement (accessed March 28, 2010)

United Nations Global Compact www.unglobalcompact.org (accessed February 19, 2010)

United Nations Millennium Development Goals (2000) http://www.un.org/millenniumgoals/poverty.shtml (accessed March 28, 2010) 
United Nations Permanent Forum on Indigenous Issues 'Structure within ECOSOC' http://www.un.org/esa/socdev/unpfii/en/structure.html , (accessed March 28, 2010)

UN-NGLS. 'Interview with Magdalena Sepulveda Carmona, independent expert on human rights and extreme poverty.' http://www.un-ngls.org/spip.php?page=article s\&id article=597 (accessed February 19, 2010)

UN-NGLS 'Structure and Staff' http://www.un-ngls.org/spip.php?page=article s\&id article=704 (accessed March 28, 2010)

United Nations Office of the United Nations High Commissioner for Human Rights. 'The draft guiding principles on extreme poverty and human rights: the rights of the poor' http://www2.ohchr.org/english/issues/poverty/consultation/index.htm (accessed March 28, 2010)

UN Webcast of the Civil Society Hearings, Freedom From Fear Cluster, 24 June 2005, http://www.un.org/ga/civilsocietyhearings/webcast.html (accessed March 15, 2010)

UN Webcast of the Civil Society Hearings, Freedom from Want Cluster, 23 June 2005, Introductory comments, Chair of the Hearings, Jean Ping, http://www.un.org/ga/civilsocietyhearings/webcast.html (accessed March 15, 2010)

Walley, Christine. "Searching for "Voices": Feminism, Anthropology, and the Global Debate over Female Genital Operations." Cultural Anthropology, Vol. 12, No. 3 (1997): 405-438

WEDO. 'Join WEDO in urging UN Secretary-General Ban Ki-moon to appoint women to the High-Level Advisory Group on Climate Change Financing' http://www.wedo.org/learn/campaigns/climatechange/join-wedo-in-urging-un-secretary-generalban-ki-moon-to-appoint-women-to-the-high-level-advisory-group-on-climate-change-financing (accessed March 15 2010)

WEDO. http://www.wedo.org/wp-content/uploads/Open-Letter-to-UN-SG.pdf (accessed March 15 2010)

Weiss, Thomas et al. "The 'Third' United Nations." Global Governance, Vol. 15 (2009): 123-142

Wodon, Quentin and Godinot, Xavier (eds.) Participatory Approaches to Attacking Extreme Poverty, (World Bank Working Paper 77: 2006) 
World Bank. Attacking Extreme Poverty: Learning from the Experience of the International Movement ATD Fourth World, World Bank Technical Paper no. 502, 2001

World Bank. Participatory approaches to Attacking Extreme Poverty: Case Studies Led by the International Movement ATD Fourth World. World Bank Working Paper 77, 2006

World Summit for Social Development, Copenhagen, (1995) http://www.un.org/esa/socdev/wssd/textversion/index.html (accessed March 19, 2010)

Wresinski, Joseph. Chronic Poverty and Lack of Basic Security. Landover, Maryland: Fourth World Publications, 1994

Wresinski, Joseph. The Very Poor: Living Proof of the Indivisibility of Human Rights. (1989) http://www.joseph-wresinski.org/THE-VERY-POOR-LIVING-PROOF-OF-THE.html (accessed March 4, 2010)

Žižek, Slavoj. "Welcome to the Desert of the Real!" The South Atlantic Quarterly, 101, 2, (2002): 385-389 